\title{
Opioid receptors in GtoPdb v.2021.3
}

Anna Borsodi ${ }^{1}$, Michael Bruchas ${ }^{2}$, Girolamo Caló ${ }^{3}$, Charles Chavkin ${ }^{4}$, MacDonald J. Christie ${ }^{5}$, Olivier Civelli $^{6}$, Mark Connor ${ }^{7}$, Brian M. Cox ${ }^{8}$, Lakshmi A. Devi ${ }^{9}$, Christopher Evans ${ }^{10}$, Volker Höllt ${ }^{11}$, Graeme Henderson ${ }^{12}$, Stephen Husbands ${ }^{13}$, Eamonn Kelly ${ }^{12}$, Brigitte Kieffer ${ }^{14}$, Ian Kitchen ${ }^{15}$, MaryJeanne Kreek ${ }^{16}$, Lee-Yuan Liu-Chen ${ }^{17}$, Dominique Massot ${ }^{14}$, Jean-Claude Meunier ${ }^{18}$, Philip S. Portoghese $^{19}$, Stefan Schulz ${ }^{20}$, Toni S. Shippenberg ${ }^{21}$, Eric J. Simon ${ }^{22}$, Lawrence Toll ${ }^{23}$, John R. Traynor $^{24}$, Hiroshi Ueda ${ }^{25}$, Yung H. Wong ${ }^{26}$, Nurulain Zaveri ${ }^{27}$ and Andreas Zimmer ${ }^{28}$

1. Hungarian Academy Of Sciences, Hungary

2. Washington University, USA

3. University of Padova, Italy

4. University of Washington Sch Med, USA

5. University of Sydney, Australia

6. University of California, Irvine, USA

7. Macquarie University, Australia

8. Uniformed Services University, USA

9. Mount Sinai School of Medicine, USA

10. University of California Los Angeles, USA

11. Otto-von-Guericke University, Germany

12. University of Bristol, UK

13. University of Bath, UK

14. Université de Strasbourg, France

15. University of Surrey, UK

16. Rockefeller University, USA

17. Temple University, USA

18. Institute of Pharmacology and Structural Biology, France

19. University of Minnesota, USA

20. Friedrich Schiller University, Germany

21. National Institutes of Health, USA

22. New York University, USA

23. Florida Atlantic University, USA

24. University of Michigan, USA

25. Nagasaki Univ Grad Biomed Sci, Japan

26. Hong Kong University of Science and Technology, Hong Kong

27. Astraea Therapeutics, LLC, USA

28. University of Bonn, Germany

\begin{abstract}
Opioid and opioid-like receptors are activated by a variety of endogenous peptides including [Met]enkephalin (met), [Leu]enkephalin (leu), $\beta$-endorphin ( $\beta$-end), $\alpha$-neodynorphin, dynorphin A (dynA), dynorphin B (dynB), big dynorphin (Big dyn), nociceptin/orphanin FQ (N/OFQ); endomorphin1 and endomorphin-2 are also potential endogenous peptides. The Greek letter nomenclature for the opioid receptors, $\mu, \delta$ and $\mathrm{K}$, is well established, and NC-IUPHAR considers this nomenclature appropriate, along with the symbols spelled out (mu, delta, and kappa), and the acronyms, MOP, DOP, and KOP. [121, 100, 91]. The human N/OFQ receptor, NOP, is considered 'opioid-related' rather than opioid because, while it exhibits a high degree of structural homology with the conventional opioid receptors [294], it displays a distinct pharmacology. Currently there are numerous clinically used drugs, such as morphine and many other opioid analgesics, as well as antagonists such as naloxone, however only for the $\mu$ receptor.
\end{abstract}

\section{Contents}

This is a citation summary for Opioid receptors in the Guide to Pharmacology database (GtoPdb). It 
exists purely as an adjunct to the database to facilitate the recognition of citations to and from the database by citation analyzers. Readers will almost certainly want to visit the relevant sections of the database which are given here under database links.

GtoPdb is an expert-driven guide to pharmacological targets and the substances that act on them. GtoPdb is a reference work which is most usefully represented as an on-line database. As in any publication this work should be appropriately cited, and the papers it cites should also be recognized. This document provides a citation for the relevant parts of the database, and also provides a reference list for the research cited by those parts. For further details see [44].

Please note that the database version for the citations given in GtoPdb are to the most recent preceding version in which the family or its subfamilies and targets were substantially changed. The links below are to the current version. If you need to consult the cited version, rather than the most recent version, please contact the GtoPdb curators.

\section{Database links}

Opioid receptors

https://www.guidetopharmacology.org/GRAC/FamilyDisplayForward?familyId=50

Introduction to Opioid receptors

https://www.guidetopharmacology.org/GRAC/FamilyIntroductionForward?familyId $=50$

Receptors
$\delta$ receptor
https://www.guidetopharmacology.org/GRAC/ObjectDisplayForward?objectId=317
K receptor
https://www.guidetopharmacology.org/GRAC/ObjectDisplayForward?objectId=318
$\mu$ receptor
https://www.guidetopharmacology.org/GRAC/ObjectDisplayForward?objectId=319
NOP receptor
https://www.guidetopharmacology.org/GRAC/ObjectDisplayForward?objectId=320

\section{References}

1. Abbadie C, Pan YX and Pasternak GW. (2000) Differential distribution in rat brain of mu opioid receptor carboxy terminal splice variants MOR-1C-like and MOR-1-like immunoreactivity: evidence for region-specific processing. J Comp Neurol 419: 244-56 [PMID:10723002]

2. Abbadie C, Pan YX and Pasternak GW. (2004) Immunohistochemical study of the expression of exon11-containing mu opioid receptor variants in mouse brain. Neuroscience 127: 419-30 [PMID:15262332]

3. Abbadie C and Pasternak GW. (2001) Differential in vivo internalization of MOR-1 and MOR-1C by morphine. Neuroreport 12: 3069-72 [PMID:11568638]

4. Abood ME, Noel MA, Farnsworth JS and Tao Q. (1994) Molecular cloning and expression of a delta-opioid receptor from rat brain. J Neurosci Res 37: 714-9 [PMID:7519274]

5. Adapa ID and Toll L. (1997) Relationship between binding affinity and functional activity of nociceptin/orphanin FQ. Neuropeptides 31: 403-8 [PMID:9413015]

6. Adler MW and Geller EB. (1987) Hypothermia and poikilothermia induced by a kappa-agonist opioid and a neuroleptic. Eur J Pharmacol 140: 233-7 [PMID:2889606]

7. Akiyama K, Gee KW, Mosberg HI, Hruby VJ and Yamamura HI. (1985) Characterization of [3H] [2-D-penicillamine, 5-D-penicillamine]-enkephalin binding to delta opiate receptors in the rat brain and neuroblastoma--glioma hybrid cell line (NG 108-15). Proc Natl Acad Sci USA 82: 2543-7 [PMID:2986120]

8. Andero R, Brothers SP, Jovanovic T, Chen YT, Salah-Uddin H, Cameron M, Bannister TD, Almli L, Stevens JS and Bradley B et al.. (2013) Amygdala-dependent fear is regulated by Oprl1 in mice and humans with PTSD. Sci Transl Med 5: 188 ra73 [PMID:23740899]

9. Andreev N, Urban L and Dray A. (1994) Opioids suppress spontaneous activity of polymodal nociceptors in rat paw skin induced by ultraviolet irradiation. Neuroscience 58: 793-8 [PMID:8190256]

10. Ann DK, Hasegawa J, Ko JL, Chen ST, Lee NM and Loh HH. (1992) Specific reduction of deltaopioid receptor binding in transfected NG108-15 cells. J Biol Chem 267: 7921-6 [PMID:1313812]

11. Arcuri L, Novello S, Frassineti M, Mercatelli D, Pisanò CA, Morella I, Fasano S, Journigan BV, Meyer ME and Polgar WE et al.. (2018) Anti-Parkinsonian and anti-dyskinetic profiles of two novel potent and selective nociceptin/orphanin FQ receptor agonists. BrJ Pharmacol 175: 782796 [PMID:29232769]

12. Arora S, Keenan SM, Peng Y, Welsh W and Zhang Q.. (2006) Opioid receptor subtype-selective agents. Patent number: WO2006124687 A1. 
13. Arvidsson U, Riedl M, Chakrabarti S, Lee JH, Nakano AH, Dado RJ, Loh HH, Law PY, Wessendorf MW and Elde R. (1995) Distribution and targeting of a mu-opioid receptor (MOR1) in brain and spinal cord. J Neurosci 15: 3328-41 [PMID:7751913]

14. Arvidsson U, Riedl M, Chakrabarti S, Vulchanova L, Lee JH, Nakano AH, Lin X, Loh HH, Law PY and Wessendorf MW et al.. (1995) The kappa-opioid receptor is primarily postsynaptic: combined immunohistochemical localization of the receptor and endogenous opioids. Proc Natl Acad Sci USA 92: 5062-6 [PMID:7539141]

15. Attali B and Vogel Z. (1986) Inhibition of adenylate cyclase and induction of heterologous desensitization by kappa agonists in rat spinal cord. NIDA Res Monogr 75: 141-4 [PMID:2828959]

16. Avidor-Reiss T, Nevo I, Saya D, Bayewitch M and Vogel Z. (1997) Opiate-induced adenylyl cyclase superactivation is isozyme-specific. J Biol Chem 272: 5040-7 [PMID:9030567]

17. Avidor-Reiss T, Zippel R, Levy R, Saya D, Ezra V, Barg J, Matus-Leibovitch N and Vogel Z. (1995) kappa-Opioid receptor-transfected cell lines: modulation of adenylyl cyclase activity following acute and chronic opioid treatments. FEBS Lett 361: 70-4 [PMID:7890042]

18. Bagnol D, Mansour A, Akil H and Watson SJ. (1997) Cellular localization and distribution of the cloned mu and kappa opioid receptors in rat gastrointestinal tract. Neuroscience 81: 579-91 [PMID:9300443]

19. Baptista-Hon DT, Smith M, Singleton S, Antonides LH, Nic Daeid N, McKenzie C and Hales TG. (2020) Activation of $\mu$-opioid receptors by MT-45 (1-cyclohexyl-4-(1,2-diphenylethyl)piperazine) and its fluorinated derivatives. BrJ Pharmacol 177: 3436-3448 [PMID:32246840]

20. Becker A, Grecksch G, Brödemann R, Kraus J, Peters B, Schroeder H, Thiemann W, Loh HH and Höllt V. (2000) Morphine self-administration in mu-opioid receptor-deficient mice. Naunyn Schmiedebergs Arch Pharmacol 361: 584-9 [PMID:10882032]

21. Becker A, Grecksch G, Kraus J, Loh HH, Schroeder H and Höllt V. (2002) Rewarding effects of ethanol and cocaine in mu opioid receptor-deficient mice. Naunyn Schmiedebergs Arch Pharmacol 365: 296-302 [PMID:11919654]

22. Becker JA, Wallace A, Garzon A, Ingallinella P, Bianchi E, Cortese R, Simonin F, Kieffer BL and Pessi A. (1999) Ligands for kappa-opioid and ORL1 receptors identified from a conformationally constrained peptide combinatorial library. J Biol Chem 274: 27513-22 [PMID:10488086]

23. BECKETT AH and CASY AF. (1954) Synthetic analgesics: stereochemical considerations. $J$ Pharm Pharmacol 6: 986-1001 [PMID:13212680]

24. Befort K, Filliol D, Decaillot FM, Gaveriaux-Ruff C, Hoehe MR and Kieffer BL. (2001) A single nucleotide polymorphic mutation in the human mu-opioid receptor severely impairs receptor signaling. J Biol Chem 276: 3130-7 [PMID:11067846]

25. Belcheva MM, Szùcs M, Wang D, Sadee W and Coscia CJ. (2001) mu-Opioid receptor-mediated ERK activation involves calmodulin-dependent epidermal growth factor receptor transactivation. J Biol Chem 276: 33847-53 [PMID:11457825]

26. Belkowski SM, Zhu J, Liu-Chen LY, Eisenstein TK, Adler MW and Rogers TJ. (1995) Sequence of kappa-opioid receptor cDNA in the R1.1 thymoma cell line. J Neuroimmunol 62: 113-7 [PMID:7499487]

27. Berrendero F, Kieffer BL and Maldonado R. (2002) Attenuation of nicotine-induced antinociception, rewarding effects, and dependence in mu-opioid receptor knock-out mice. $J$ Neurosci 22: 10935-40 [PMID:12486188]

28. Berthele A, Platzer S, Dworzak D, Schadrack J, Mahal B, Büttner A, Assmus HP, Wurster K, Zieglgänsberger W and Conrad B et al.. (2003) [3H]-nociceptin ligand-binding and nociceptin opioid receptor mrna expression in the human brain. Neuroscience 121: 629-40 [PMID:14568023]

29. Berzetei-Gurske IP, Schwartz RW and Toll L. (1996) Determination of activity for nociceptin in the mouse vas deferens. Eur J Pharmacol 302: R1-2 [PMID:8791013]

30. Besse D, Lombard MC and Besson JM. (1991) Autoradiographic distribution of mu, delta and kappa opioid binding sites in the superficial dorsal horn, over the rostrocaudal axis of the rat spinal cord. Brain Res 548: 287-91 [PMID:1651143]

31. Besse D, Lombard MC, Zajac JM, Roques BP and Besson JM. (1990) Pre- and postsynaptic distribution of $\mathrm{mu}$, delta and kappa opioid receptors in the superficial layers of the cervical dorsal horn of the rat spinal cord. Brain Res 521: 15-22 [PMID:2169958]

32. Bhushan RG, Sharma SK, Xie Z, Daniels DJ and Portoghese PS. (2004) A bivalent ligand (KDN21) reveals spinal delta and kappa opioid receptors are organized as heterodimers that give rise to delta(1) and kappa(2) phenotypes. Selective targeting of delta-kappa heterodimers. J Med Chem 47: 2969-2972 [PMID:15163177]

33. Bigoni R, Giuliani S, Calo' G, Rizzi A, Guerrini R, Salvadori S, Regoli D and Maggi CA. (1999) Characterization of nociceptin receptors in the periphery: in vitro and in vivo studies. Naunyn Schmiedebergs Arch Pharmacol 359: 160-7 [PMID:10208302]

34. Bigoni R, Rizzi D, Rizzi A, Camarda V, Guerrini R, Lambert DG, Hashiba E, Berger H, Salvadori S and Regoli D et al.. (2002) Pharmacological characterisation of [(pX)Phe4]nociceptin(1- 
13)amide analogues. 1. In vitro studies. Naunyn Schmiedebergs Arch Pharmacol 365: 442-9 [PMID:12070757]

35. Birgül N, Weise C, Kreienkamp HJ and Richter D. (1999) Reverse physiology in drosophila: identification of a novel allatostatin-like neuropeptide and its cognate receptor structurally related to the mammalian somatostatin/galanin/opioid receptor family. EMBO J 18: 5892-900 [PMID:10545101]

36. Blackburn TP, Cross AJ, Hille C and Slater P. (1988) Autoradiographic localization of delta opiate receptors in rat and human brain. Neuroscience 27: 497-506 [PMID:2851117]

37. Bohn LM, Belcheva MM and Coscia CJ. (2000) Mitogenic signaling via endogenous kappa-opioid receptors in C6 glioma cells: evidence for the involvement of protein kinase $\mathrm{C}$ and the mitogenactivated protein kinase signaling cascade. J Neurochem 74: 564-73 [PMID:10646507]

38. Bolan EA, Pan YX and Pasternak GW. (2004) Functional analysis of MOR-1 splice variants of the mouse mu opioid receptor gene Oprm. Synapse 51: 11-8 [PMID:14579421]

39. Bond C, LaForge KS, Tian M, Melia D, Zhang S, Borg L, Gong J, Schluger J, Strong JA and Leal SM et al.. (1998) Single-nucleotide polymorphism in the human mu opioid receptor gene alters beta-endorphin binding and activity: possible implications for opiate addiction. Proc Natl Acad Sci USA 95: 9608-13 [PMID:9689128]

40. Bourinet E, Soong TW, Stea A and Snutch TP. (1996) Determinants of the G protein-dependent opioid modulation of neuronal calcium channels. Proc Natl Acad Sci USA 93: 1486-91 [PMID:8643659]

41. Breslin HJ, Diamond CJ, Kavash RW, Cai C, Dyatkin AB, Miskowski TA, Zhang SP, Wade PR, Hornby PJ and He W. (2012) Identification of a dual $\delta$ OR antagonist/ $\mu$ OR agonist as a potential therapeutic for diarrhea-predominant Irritable Bowel Syndrome (IBS-d). Bioorg Med Chem Lett 22: 4869-72 [PMID:22695132]

42. Broom DC, Guo L, Coop A, Husbands SM, Lewis JW, Woods JH and Traynor JR. (2000) BU48: a novel buprenorphine analog that exhibits delta-opioid-mediated convulsions but not delta-opioidmediated antinociception in mice. J Pharmacol Exp Ther 294: 1195-200 [PMID:10945877]

43. Bruchas MR, Yang T, Schreiber S, Defino M, Kwan SC, Li S and Chavkin C. (2007) Long-acting kappa opioid antagonists disrupt receptor signaling and produce noncompetitive effects by activating c-Jun N-terminal kinase. J Biol Chem 282: 29803-11 [PMID:17702750]

44. Buneman P, Christie G, Davies JA, Dimitrellou R, Harding SD, Pawson AJ, Sharman JL and Wu Y. (2020) Why data citation isn't working, and what to do about it Database 2020 [PMID:32367113]

45. Bunzow JR, Saez C, Mortrud M, Bouvier C, Williams JT, Low M and Grandy DK. (1994) Molecular cloning and tissue distribution of a putative member of the rat opioid receptor gene family that is not a mu, delta or kappa opioid receptor type. FEBS Lett 347: 284-8 [PMID:8034019]

46. Burford NT, Clark MJ, Wehrman TS, Gerritz SW, Banks M, O'Connell J, Traynor JR and Alt A. (2013) Discovery of positive allosteric modulators and silent allosteric modulators of the $\mu$-opioid receptor. Proc Natl Acad Sci USA 110: 10830-5 [PMID:23754417]

47. Burford NT, Livingston KE, Canals M, Ryan MR, Budenholzer LM, Han Y, Shang Y, Herbst JJ, O'Connell J and Banks M et al.. (2015) Discovery, Synthesis, and Molecular Pharmacology of Selective Positive Allosteric Modulators of the 6-Opioid Receptor. J Med Chem 58: 4220-9 [PMID:25901762]

48. Béguin C, Richards MR, Wang Y, Chen Y, Liu-Chen LY, Ma Z, Lee DY, Carlezon Jr WA and Cohen BM. (2005) Synthesis and in vitro pharmacological evaluation of salvinorin A analogues modified at C(2). Bioorg Med Chem Lett 15: 2761-5 [PMID:15869877]

49. Búzás B, Tóth G, Cavagnero S, Hruby VJ and Borsodi A. (1992) Synthesis and binding characteristics of the highly delta-specific new tritiated opioid peptide, [3H]deltorphin II. Life Sci 50: PL75-8 [PMID:1313131]

50. Cahill CM, Morinville A, Hoffert C, O'Donnell D and Beaudet A. (2003) Up-regulation and trafficking of delta opioid receptor in a model of chronic inflammation: implications for pain control. Pain 101: 199-208 [PMID:12507715]

51. Calderon SN, Rothman RB, Porreca F, Flippen-Anderson JL, McNutt RW, Xu H, Smith LE, Bilsky EJ, Davis P and Rice KC. (1994) Probes for narcotic receptor mediated phenomena. 19. Synthesis of (+)-4-[(alpha R)-alpha-((2S,5R)-4-allyl-2,5-dimethyl-1-piperazinyl)-3methoxybenzyl]-N,N-diethylbenzamide (SNC 80): a highly selective, nonpeptide delta opioid receptor agonist. J Med Chem 37: 2125-8 [PMID:8035418]

52. Calo G, Guerrini R, Rizzi A, Salvadori S, Burmeister M, Kapusta DR, Lambert DG and Regoli D. (2005) UFP-101, a peptide antagonist selective for the nociceptin/orphanin FQ receptor. CNS Drug Rev 11: 97-112 [PMID:16007234]

53. Calo G, Rizzi A, Rizzi D, Bigoni R, Guerrini R, Marzola G, Marti M, McDonald J, Morari M and Lambert DG et al.. (2002) [Nphe1,Arg14,Lys15]nociceptin-NH2, a novel potent and selective antagonist of the nociceptin/orphanin FQ receptor. Br J Pharmacol 136: 303-11 [PMID:12010780] 
54. Calo' G, Bigoni R, Rizzi A, Guerrini R, Salvadori S and Regoli D. (2000) Nociceptin/orphanin FQ receptor ligands. Peptides 21: 935-47 [PMID:10998527]

55. Calo' G, Guerrini R, Bigoni R, Rizzi A, Marzola G, Okawa H, Bianchi C, Lambert DG, Salvadori S and Regoli D. (2000) Characterization of [Nphe(1)]nociceptin(1-13)NH(2), a new selective nociceptin receptor antagonist. Br J Pharmacol 129: 1183-93 [PMID:10725267]

56. Calò G, Rizzi A, Bogoni G, Neugebauer V, Salvadori S, Guerrini R, Bianchi C and Regoli D. (1996) The mouse vas deferens: a pharmacological preparation sensitive to nociceptin. Eur J Pharmacol 311: R3-5 [PMID:8884244]

57. Camarda V, Fischetti C, Anzellotti N, Molinari P, Ambrosio C, Kostenis E, Regoli D, Trapella C, Guerrini R and Severo S et al.. (2009) Pharmacological profile of NOP receptors coupled with calcium signaling via the chimeric protein G alpha qi5. Naunyn Schmiedebergs Arch Pharmacol 379: 599-607 [PMID:19183962]

58. Carrà G, Rizzi A, Guerrini R, Barnes TA, McDonald J, Hebbes CP, Mela F, Kenigs VA, Marzola G and Rizzi D et al.. (2005) [(pF)Phe4,Arg14,Lys15]N/OFQ-NH2 (UFP-102), a highly potent and selective agonist of the nociceptin/orphanin FQ receptor. J Pharmacol Exp Ther 312: 1114-23 [PMID:15509719]

59. Carter BD and Medzihradsky F. (1993) Go mediates the coupling of the mu opioid receptor to adenylyl cyclase in cloned neural cells and brain. Proc Natl Acad Sci USA 90: 4062-6 [PMID:8097884]

60. Chan JS, Chiu TT and Wong YH. (1995) Activation of type II adenylyl cyclase by the cloned muopioid receptor: coupling to multiple G proteins. J Neurochem 65: 2682-9 [PMID:7595566]

61. Chang KJ, Rigdon GC, Howard JL and McNutt RW. (1993) A novel, potent and selective nonpeptidic delta opioid receptor agonist BW373U86. J Pharmacol Exp Ther 267: 852-7 [PMID:8246159]

62. Chang KJ, Wei ET, Killian A and Chang JK. (1983) Potent morphiceptin analogs: structure activity relationships and morphine-like activities. J Pharmacol Exp Ther 227: 403-8 [PMID:6313901]

63. Chang SD, Mascarella SW, Spangler SM, Gurevich VV, Navarro HA, Carroll FI and Bruchas MR. (2015) Quantitative Signaling and Structure-Activity Analyses Demonstrate Functional Selectivity at the Nociceptin/Orphanin FQ Opioid Receptor. Mol Pharmacol 88: 502-11 [PMID:26134494]

64. Chao CC, Gekker G, Hu S, Sheng WS, Shark KB, Bu DF, Archer S, Bidlack JM and Peterson PK. (1996) kappa opioid receptors in human microglia downregulate human immunodeficiency virus 1 expression. Proc Natl Acad Sci USA 93: 8051-6 [PMID:8755601]

65. Chavkin C, James IF and Goldstein A. (1982) Dynorphin is a specific endogenous ligand of the kappa opioid receptor. Science 215: 413-5 [PMID:6120570]

66. Chavkin C, Sud S, Jin W, Stewart J, Zjawiony JK, Siebert DJ, Toth BA, Hufeisen SJ and Roth BL. (2004) Salvinorin A, an active component of the hallucinogenic sage salvia divinorum is a highly efficacious kappa-opioid receptor agonist: structural and functional considerations. J Pharmacol Exp Ther 308: 1197-203 [PMID:14718611]

67. Che T, Majumdar S, Zaidi SA, Ondachi P, McCorvy JD, Wang S, Mosier PD, Uprety R, Vardy E and Krumm BE et al.. (2018) Structure of the Nanobody-Stabilized Active State of the Kappa Opioid Receptor. Cell 172: 55-67.e15 [PMID:29307491]

68. Chefer VI, Kieffer BL and Shippenberg TS. (2003) Basal and morphine-evoked dopaminergic neurotransmission in the nucleus accumbens of MOR- and DOR-knockout mice. Eur J Neurosci 18: 1915-22 [PMID:14622224]

69. Chen Y, Mestek A, Liu J, Hurley JA and Yu L. (1993) Molecular cloning and functional expression of a mu-opioid receptor from rat brain. Mol Pharmacol 44: 8-12 [PMID:8393525]

70. Chen Y, Mestek A, Liu J and Yu L. (1993) Molecular cloning of a rat kappa opioid receptor reveals sequence similarities to the mu and delta opioid receptors. Biochem J 295 ( Pt 3): 625-8 [PMID:8240267]

71. Chen Z, Davies E, Miller WS, Shan S, Valenzano KJ and Kyle DJ. (2004) Design and synthesis of 4-phenyl piperidine compounds targeting the mu receptor. Bioorg Med Chem Lett 14: 5275-9 [PMID:15454210]

72. Cheney BV, Szmuszkovicz J, Lahti RA and Zichi DA. (1985) Factors affecting binding of trans-N[2-(methylamino)cyclohexyl]benzamides at the primary morphine receptor. J Med Chem $\mathbf{2 8}$ : 1853-64 [PMID:2999404]

73. Cheng JT, Liu IM and Hsu CF. (2003) Rapid induction of insulin resistance in opioid mu-receptor knock-out mice. Neurosci Lett 339: 139-42 [PMID:12614914]

74. Cheng PY, Liu-Chen LY and Pickel VM. (1997) Dual ultrastructural immunocytochemical labeling of mu and delta opioid receptors in the superficial layers of the rat cervical spinal cord. Brain Res 778: 367-80 [PMID:9459554]

75. Cheng PY, Moriwaki A, Wang JB, Uhl GR and Pickel VM. (1996) Ultrastructural localization of mu-opioid receptors in the superficial layers of the rat cervical spinal cord: extrasynaptic localization and proximity to Leu5-enkephalin. Brain Res 731: 141-54 [PMID:8883864] 
76. Chieng B, Connor M and Christie MJ. (1996) The mu-opioid receptor antagonist D-Phe-Cys-TyrD-Trp-Orn-Thr-Pen-Thr-NH2 (CTOP) [but not D-Phe-Cys-Tyr-D-Trp-Arg-Thr-Pen-Thr-NH2 (CTAP)] produces a nonopioid receptor-mediated increase in $\mathrm{K}+$ conductance of rat locus ceruleus neurons. Mol Pharmacol 50: 650-5 [PMID:8794906]

77. Christopoulos A and Kenakin T. (2002) G protein-coupled receptor allosterism and complexing. Pharmacol Rev 54: 323-74 [PMID:12037145]

78. Chuang TK, Killam Jr KF, Chuang LF, Kung HF, Sheng WS, Chao CC, Yu L and Chuang RY. (1995) $\mathrm{Mu}$ opioid receptor gene expression in immune cells. Biochem Biophys Res Commun 216: 922-30 [PMID:7488213]

79. Clarke S, Chen Z, Hsu MS, Hill RG, Pintar JE and Kitchen I. (2003) Nociceptin/orphanin FQ knockout mice display up-regulation of the opioid receptor-like 1 receptor and alterations in opioid receptor expression in the brain. Neuroscience 117: 157-68 [PMID:12605902]

80. Clarke S, Chen Z, Hsu MS, Pintar J, Hill R and Kitchen I. (2001) Quantitative autoradiographic mapping of the ORL1, mu-, delta- and kappa-receptors in the brains of knockout mice lacking the ORL1 receptor gene. Brain Res 906: 13-24 [PMID:11430857]

81. Clarke S, Czyzyk T, Ansonoff M, Nitsche JF, Hsu MS, Nilsson L, Larsson K, Borsodi A, Toth G, Hill R, Kitchen I and Pintar JE. (2002) Autoradiography of opioid and ORL1 ligands in opioid receptor triple knockout mice. Eur J Neurosci 16: 1705-1712 [PMID:12431223]

82. Cometta-Morini C, Maguire PA and Loew GH. (1992) Molecular determinants of mu receptor recognition for the fentanyl class of compounds. Mol Pharmacol 41: 185-96 [PMID:1310142]

83. Conibear AE, Asghar J, Hill R, Henderson G, Borbely E, Tekus V, Helyes Z, Palandri J, Bailey C and Starke I et al.. (2020) A Novel G Protein-Biased Agonist at the $\delta$ Opioid Receptor with Analgesic Efficacy in Models of Chronic Pain. J Pharmacol Exp Ther 372: 224-236 [PMID:31594792]

84. Connor M and Christie MD. (1999) Opioid receptor signalling mechanisms. Clin Exp Pharmacol Physiol 26: 493-9 [PMID:10405772]

85. Connor M, Schuller A, Pintar JE and Christie MJ. (1999) Mu-opioid receptor modulation of calcium channel current in periaqueductal grey neurons from C57B16/J mice and mutant mice lacking MOR-1. Br J Pharmacol 126: 1553-8 [PMID:10323586]

86. Connor M, Vaughan CW, Allen RS and Christie MJ. (1999) Nociceptin, $\mathrm{Phe}^{1} \psi$-nociceptin ${ }_{113}$, nocistatin and prepronociceptin ${ }_{154181}$ effects on calcium channel currents and a potassium current in rat locus coeruleusin vitro. Br J Pharmacol 128: 1779-1787 [PMID:10588934]

87. Connor M, Yeo A and Henderson G. (1996) The effect of nociceptin on Ca2+ channel current and intracellular Ca2+ in the SH-SY5Y human neuroblastoma cell line. Br J Pharmacol 118: 2057 [PMID:8735615]

88. Contarino A, Picetti R, Matthes HW, Koob GF, Kieffer BL and Gold LH. (2002) Lack of reward and locomotor stimulation induced by heroin in mu-opioid receptor-deficient mice. Eur J Pharmacol 446: 103-9 [PMID:12098591]

89. Costa T and Herz A. (1989) Antagonists with negative intrinsic activity at delta opioid receptors coupled to GTP-binding proteins. Proc Natl Acad Sci USA 86: 7321-5 [PMID:2552439]

90. Cox BM and Chavkin C. (1983) Comparison of dynorphin-selective Kappa receptors in mouse vas deferens and guinea pig ileum. Spare receptor fraction as a determinant of potency. Mol Pharmacol 23: 36-43 [PMID:6135144]

91. Cox BM, Christie MJ, Devi L, Toll L and Traynor JR. (2015) Challenges for opioid receptor nomenclature: IUPHAR Review 9. Br J Pharmacol 172: 317-23 [PMID:24528283]

92. Cox BM, Goldstein A and Hi CH. (1976) Opioid activity of a peptide, beta-lipotropin-(61-91), derived from beta-lipotropin. Proc Natl Acad Sci USA 73: 1821-3 [PMID:1064855]

93. Cvejic S and Devi LA. (1997) Dimerization of the delta opioid receptor: implication for a role in receptor internalization. J Biol Chem 272: 26959-64 [PMID:9341132]

94. Dapoigny M, Abitbol JL and Fraitag B. (1995) Efficacy of peripheral kappa agonist fedotozine versus placebo in treatment of irritable bowel syndrome. A multicenter dose-response study. Dig Dis Sci 40: 2244-9 [PMID:7587797]

95. de Costa BR, Rothman RB, Bykov V, Jacobson AE and Rice KC. (1989) Selective and enantiospecific acylation of kappa opioid receptors by (1S,2S)-trans-2-isothiocyanato-N-methyl$\mathrm{N}$-[2-(1-pyrrolidinyl) cyclohexy l] benzeneacetamide. Demonstration of kappa receptor heterogeneity. J Med Chem 32: 281-3 [PMID:2536435]

96. Dekan Z, Sianati S, Yousuf A, Sutcliffe KJ, Gillis A, Mallet C, Singh P, Jin AH, Wang AM and Mohammadi SA et al.. (2019) A tetrapeptide class of biased analgesics from an Australian fungus targets the $\mu$-opioid receptor. Proc Natl Acad Sci USA 116: 22353-22358 [PMID:31611414]

97. Delay-Goyet P, Seguin C, Gacel G and Roques BP. (1988) [3H][D-Ser2(O-tertbutyl),Leu5] enkephalyl-Thr6 and [D-Ser2(O-tert-butyl), Leu5] enkephalyl-Thr6(O-tert-butyl). Two new enkephalin analogs with both a good selectivity and a high affinity toward delta-opioid binding sites. J Biol Chem 263: 4124-30 [PMID:2831220]

98. Delfs JM, Kong H, Mestek A, Chen Y, Yu L, Reisine T and Chesselet MF. (1994) Expression of mu 
opioid receptor mRNA in rat brain: an in situ hybridization study at the single cell level. J Comp Neurol 345: 46-68 [PMID:8089277]

99. Depner UB, Reinscheid RK, Takeshima H, Brune K and Zeilhofer HU. (2003) Normal sensitivity to acute pain, but increased inflammatory hyperalgesia in mice lacking the nociceptin precursor polypeptide or the nociceptin receptor. Eur J Neurosci 17: 2381-7 [PMID:12814369]

100. Dhawan BN, Cesselin F, Raghubir R, Reisine T, Bradley PB, Portoghese PS and Hamon M. (1996) International Union of Pharmacology. XII. Classification of opioid receptors. Pharmacol Rev 48: 567-92 [PMID:8981566]

101. Di Chiara G and Imperato A. (1988) Opposite effects of mu and kappa opiate agonists on dopamine release in the nucleus accumbens and in the dorsal caudate of freely moving rats. $J$ Pharmacol Exp Ther 244: 1067-80 [PMID:2855239]

102. Di Giannuario A, Pieretti S, Catalani A and Loizzo A. (1999) Orphanin FQ reduces morphineinduced dopamine release in the nucleus accumbens: a microdialysis study in rats. Neurosci Lett 272: 183-6 [PMID:10505611]

103. Dietis N, McDonald J, Molinari S, Calo G, Guerrini R, Rowbotham DJ and Lambert DG. (2012) Pharmacological characterization of the bifunctional opioid ligand H-Dmt-Tic-Gly-NH-Bzl (UFP505). Br J Anaesth 108: 262-70 [PMID:22194444]

104. Dietis N, Niwa H, Tose R, McDonald J, Ruggieri V, Filaferro M, Vitale G, Micheli L, Ghelardini C and Salvadori S et al.. (2018) In vitro and in vivo characterization of the bifunctional $\mu$ and $\delta$ opioid receptor ligand UFP-505. Br J Pharmacol 175: 2881-2896 [PMID:29524334]

105. Ding YQ, Kaneko T, Nomura S and Mizuno N. (1996) Immunohistochemical localization of muopioid receptors in the central nervous system of the rat. J Comp Neurol 367: 375-402 [PMID:8698899]

106. Ding YQ, Nomura S, Kaneko T and Mizuno N. (1995) Presynaptic localization of mu-opioid receptor-like immunoreactivity in retinal axon terminals within the terminal nuclei of the accessory optic tract: a light and electron microscope study in the rat. Neurosci Lett 199: 13942 [PMID:8584243]

107. Ding YQ, Nomura S, Kaneko T and Mizuno N. (1995) Co-localization of mu-opioid receptor-like and substance P-like immunoreactivities in axon terminals within the superficial layers of the medullary and spinal dorsal horns of the rat. Neurosci Lett 198: 45-8 [PMID:8570093]

108. Dooley CT, Spaeth CG, Berzetei-Gurske IP, Craymer K, Adapa ID, Brandt SR, Houghten RA and Toll L. (1997) Binding and in vitro activities of peptides with high affinity for the nociceptin/orphanin FQ receptor, ORL1.J Pharmacol Exp Ther 283: 735-41 [PMID:9353393]

109. Durham RA, Johnson JD, Moore KE and Lookingland KJ. (1996) Evidence that D2 receptormediated activation of hypothalamic tuberoinfundibular dopaminergic neurons in the male rat occurs via inhibition of tonically active afferent dynorphinergic neurons. Brain Res 732: 113-20 [PMID:8891275]

110. Erbs E, Faget L, Scherrer G, Matifas A, Filliol D, Vonesch JL, Koch M, Kessler P, Hentsch D and Birling MC et al.. (2015) A mu-delta opioid receptor brain atlas reveals neuronal co-occurrence in subcortical networks. Brain Struct Funct 220: 677-702 [PMID:24623156]

111. Erspamer V, Melchiorri P, Falconieri-Erspamer G, Negri L, Corsi R, Severini C, Barra D, Simmaco M and Kreil G. (1989) Deltorphins: a family of naturally occurring peptides with high affinity and selectivity for delta opioid binding sites. Proc Natl Acad Sci USA 86: 5188-92 [PMID:2544892]

112. Evans CJ. (2004) Secrets of the opium poppy revealed. Neuropharmacology 47 Suppl 1: 293-9 [PMID:15464145]

113. Evans CJ, Keith Jr DE, Morrison H, Magendzo K and Edwards RH. (1992) Cloning of a delta opioid receptor by functional expression. Science 258: 1952-5 [PMID:1335167]

114. Fan XL, Zhang JS, Zhang XQ and Ma L. (2003) Chronic morphine treatment and withdrawal induce up-regulation of c-Jun N-terminal kinase 3 gene expression in rat brain. Neuroscience 122: 997-1002 [PMID:14643766]

115. Fenalti G, Giguere PM, Katritch V, Huang XP, Thompson AA, Cherezov V, Roth BL and Stevens RC. (2014) Molecular control of 8 -opioid receptor signalling. Nature 506: 191-6 [PMID:24413399]

116. Fernandez F, Misilmeri MA, Felger JC and Devine DP. (2004) Nociceptin/orphanin FQ increases anxiety-related behavior and circulating levels of corticosterone during neophobic tests of anxiety. Neuropsychopharmacology 29: 59-71 [PMID:14532912]

117. Ferrari F, Rizzo S, Ruzza C and Calo G. (2020) Detailed In Vitro Pharmacological Characterization of the Clinically Viable Nociceptin/Orphanin FQ Peptide Receptor Antagonist BTRX-246040. J Pharmacol Exp Ther 373: 34-43 [PMID:31937563]

118. Filliol D, Ghozland S, Chluba J, Martin M, Matthes HW, Simonin F, Befort K, Gavériaux-Ruff C, Dierich A and LeMeur M et al.. (2000) Mice deficient for delta- and mu-opioid receptors exhibit opposing alterations of emotional responses. Nat Genet 25: 195-200 [PMID:10835636]

119. Fischetti C, Camarda V, Rizzi A, Pelà M, Trapella C, Guerrini R, McDonald J, Lambert DG, Salvadori S and Regoli D et al.. (2009) Pharmacological characterization of the 
nociceptin/orphanin FQ receptor non peptide antagonist Compound 24. Eur J Pharmacol 614: 50-7 [PMID:19445927]

120. Florin S, Meunier J and Costentin J. (2000) Autoradiographic localization of [3H]nociceptin binding sites in the rat brain. Brain Res 880: 11-6 [PMID:11032985]

121. Foord SM, Bonner TI, Neubig RR, Rosser EM, Pin JP, Davenport AP, Spedding M and Harmar AJ. (2005) International Union of Pharmacology. XLVI. G protein-coupled receptor list. Pharmacol Rev 57: 279-88 [PMID:15914470]

122. Fraser GL, Gaudreau GA, Clarke PB, Ménard DP and Perkins MN. (2000) Antihyperalgesic effects of delta opioid agonists in a rat model of chronic inflammation. Br J Pharmacol 129: 1668-72 [PMID:10780972]

123. Fujii H, Kawai K, Kawamura K, Mizusuna A, Onoda Y, Murachi M, Tanaka T, Endoh T and Nagase H. (2001) Synthesis of optically active TAN-67, a highly selective delta opioid receptor agonist, and investigation of its pharmacological properties. Drug Des Discov 17: 325-30 [PMID:11765135]

124. Fukuda K, Kato S, Mori K, Nishi M and Takeshima H. (1993) Primary structures and expression from cDNAs of rat opioid receptor delta- and mu-subtypes. FEBS Lett 327: 311-314 [PMID:8394245]

125. Fukuda K, Kato S, Morikawa H, Shoda T and Mori K. (1996) Functional coupling of the delta-, mu-, and kappa-opioid receptors to mitogen-activated protein kinase and arachidonate release in Chinese hamster ovary cells. J Neurochem 67: 1309-16 [PMID:8752140]

126. Fulton BS, Knapp BI, Bidlack JM and Neumeyer JL. (2008) Synthesis and pharmacological evaluation of hydrophobic esters and ethers of butorphanol at opioid receptors. Bioorg Med Chem Lett 18: 4474-6 [PMID:18674902]

127. Gavioli EC, Marzola G, Guerrini R, Bertorelli R, Zucchini S, De Lima TC, Rae GA, Salvadori S, Regoli D and Calo G. (2003) Blockade of nociceptin/orphanin FQ-NOP receptor signalling produces antidepressant-like effects: pharmacological and genetic evidences from the mouse forced swimming test. Eur J Neurosci 17: 1987-90 [PMID:12752799]

128. Gavériaux C, Peluso J, Simonin F, Laforet J and Kieffer B. (1995) Identification of kappa- and delta-opioid receptor transcripts in immune cells. FEBS Lett 369: 272-6 [PMID:7649271]

129. Gavériaux-Ruff C and Kieffer BL. (2002) Opioid receptor genes inactivated in mice: the highlights. Neuropeptides 36: 62-71 [PMID:12359497]

130. Gavériaux-Ruff C, Matthes HW, Peluso J and Kieffer BL. (1998) Abolition of morphineimmunosuppression in mice lacking the mu-opioid receptor gene. Proc Natl Acad Sci USA 95: 6326-30 [PMID:9600964]

131. Gavériaux-Ruff C, Simonin F, Filliol D and Kieffer BL. (2003) Enhanced humoral response in kappa-opioid receptor knockout mice. J Neuroimmunol 134: 72-81 [PMID:12507774]

132. George SR, Fan T, Xie Z, Tse R, Tam V, Varghese G and O'Dowd BF. (2000) Oligomerization of mu- and delta-opioid receptors. Generation of novel functional properties. J Biol Chem 275: 26128-35 [PMID:10842167]

133. George SR, Zastawny RL, Briones-Urbina R, Cheng R, Nguyen T, Heiber M, Kouvelas A, Chan AS and O'Dowd BF. (1994) Distinct distributions of $\mathrm{mu}$, delta and kappa opioid receptor mRNA in rat brain. Biochem Biophys Res Commun 205: 1438-44 [PMID:7802680]

134. Ghozland S, Matthes HW, Simonin F, Filliol D, Kieffer BL and Maldonado R. (2002) Motivational effects of cannabinoids are mediated by mu-opioid and kappa-opioid receptors. J Neurosci 22: 1146-54 [PMID:11826143]

135. Glick SD, Maisonneuve IM, Raucci J and Archer S. (1995) Kappa opioid inhibition of morphine and cocaine self-administration in rats. Brain Res 681: 147-52 [PMID:7552272]

136. Gmerek DE and Cowan A. (1988) Role of opioid receptors in bombesin-induced grooming. Ann $N$ Y Acad Sci 525: 291-300 [PMID:2839069]

137. Goldstein A and Naidu A. (1989) Multiple opioid receptors: ligand selectivity profiles and binding site signatures. Mol Pharmacol 36: 265-72 [PMID:2549383]

138. Goldstein A, Tachibana S, Lowney LI, Hunkapiller M and Hood L. (1979) Dynorphin-(1-13), an extraordinarily potent opioid peptide. Proc Natl Acad Sci USA 76: 6666-70 [PMID:230519]

139. Gomes I, Jordan BA, Gupta A, Trapaidze N, Nagy V and Devi LA. (2000) Heterodimerization of mu and delta opioid receptors: A role in opiate synergy. J Neurosci 20: RC110 [PMID:11069979]

140. Gong J, Strong JA, Zhang S, Yue X, DeHaven RN, Daubert JD, Cassel JA, Yu G, Mansson E and $\mathrm{Yu}$ L. (1998) Endomorphins fully activate a cloned human mu opioid receptor. FEBS Lett 439: 152-6 [PMID:9849897]

141. Goody RJ, Oakley SM, Filliol D, Kieffer BL and Kitchen I. (2002) Quantitative autoradiographic mapping of opioid receptors in the brain of delta-opioid receptor gene knockout mice. Brain Res 945: 9-19 [PMID:12113946]

142. Goto Y, Arai-Otsuki S, Tachibana Y, Ichikawa D, Ozaki S, Takahashi H, Iwasawa Y, Okamoto O, Okuda S and Ohta H et al.. (2006) Identification of a novel spiropiperidine opioid receptor-like 1 antagonist class by a focused library approach featuring 3D-pharmacophore similarity. J Med Chem 49: 847-9 [PMID:16451050] 
143. Gottschlich R, Ackermann KA, Barber A, Bartoszyk GD and Greiner HE. (1994) EMD 61753 as a favourable representative of structurally novel arylacetamido-type K opiate receptor agonists Bioorg Med Chem Lett 4: 677-682

144. Granier S, Manglik A, Kruse AC, Kobilka TS, Thian FS, Weis WI and Kobilka BK. (2012) Structure of the $\delta$-opioid receptor bound to naltrindole. Nature 485: 400-4 [PMID:22596164]

145. Grevel J, Yu V and Sadée W. (1985) Characterization of a labile naloxone binding site (lambda site) in rat brain. J Neurochem 44: 1647-56 [PMID:2985759]

146. Grisel JE, Mogil JS, Belknap JK and Grandy DK. (1996) Orphanin FQ acts as a supraspinal, but not a spinal, anti-opioid peptide. Neuroreport 7: 2125-9 [PMID:8930972]

147. Grudt TJ and Williams JT. (1993) kappa-Opioid receptors also increase potassium conductance. Proc Natl Acad Sci USA 90: 11429-32 [PMID:7902584]

148. Guan JS, Xu ZZ, Gao H, He SQ, Ma GQ, Sun T, Wang LH, Zhang ZN, Lena I and Kitchen I et al.. (2005) Interaction with vesicle luminal protachykinin regulates surface expression of deltaopioid receptors and opioid analgesia. Cell 122: 619-31 [PMID:16122428]

149. Guerrero M, Urbano M, Kim EK, Gamo AM, Riley S, Abgaryan L, Leaf N, Van Orden LJ, Brown SJ and Xie JY et al.. (2019) Design and Synthesis of a Novel and Selective Kappa Opioid Receptor (KOR) Antagonist (BTRX-335140). J Med Chem 62: 1761-1780 [PMID:30707578]

150. Guerrini R, Calo G, Rizzi A, Bianchi C, Lazarus LH, Salvadori S, Temussi PA and Regoli D. (1997) Address and message sequences for the nociceptin receptor: a structure-activity study of nociceptin-(1-13)-peptide amide. J Med Chem 40: 1789-93 [PMID:9191955]

151. Guerrini R, Calo G, Rizzi A, Bigoni R, Bianchi C, Salvadori S and Regoli D. (1998) A new selective antagonist of the nociceptin receptor. Br J Pharmacol 123: 163-5 [PMID:9489602]

152. Guerrini R, Caló G, Lambert DG, Carrá G, Arduin M, Barnes TA, McDonald J, Rizzi D, Trapella C and Marzola E et al.. (2005) N- and C-terminal modifications of nociceptin/orphanin FQ generate highly potent NOP receptor ligands. J Med Chem 48: 1421-7 [PMID:15743186]

153. Hall FS, Goeb M, Li XF, Sora I and Uhl GR. (2004) mu-Opioid receptor knockout mice display reduced cocaine conditioned place preference but enhanced sensitization of cocaine-induced locomotion. Brain Res Mol Brain Res 121: 123-30 [PMID:14969743]

154. Hall FS, Sora I and Uhl GR. (2001) Ethanol consumption and reward are decreased in mu-opiate receptor knockout mice. Psychopharmacology (Berl.) 154: 43-9 [PMID:11292005]

155. Handa BK, Land AC, Lord JA, Morgan BA, Rance MJ and Smith CF. (1981) Analogues of betaLPH61-64 possessing selective agonist activity at mu-opiate receptors. Eur J Pharmacol 70: 53140 [PMID:6263640]

156. Handler CM, Geller EB and Adler MW. (1992) Effect of mu-, kappa-, and delta-selective opioid agonists on thermoregulation in the rat. Pharmacol Biochem Behav 43: 1209-16 [PMID:1361992]

157. Hanessian S, Parthasarathy S, Mauduit M and Payza K. (2003) The power of visual imagery in drug design. Isopavines as a new class of morphinomimetics and their human opioid receptor binding activity. J Med Chem 46: 34-48 [PMID:12502358]

158. Hanner M, Moebius FF, Flandorfer A and Glossmann H. (1996) Purification, molecular cloning, and expression of the mammalian sigma ${ }_{1}$-binding site. Proc Natl Acad Sci USA 93: 8072-8077 [PMID:8755605]

159. Hawes BE, Graziano MP and Lambert DG. (2000) Cellular actions of nociceptin: transduction mechanisms. Peptides 21: 961-967 [PMID:10998529]

160. Hawkins KN, Knapp RJ, Gehlert DR, Lui GK, Yamamura MS, Roeske LC, Hruby VJ and Yamamura HI. (1988) Quantitative autoradiography of [3H]CTOP binding to mu opioid receptors in rat brain. Life Sci 42: 2541-51 [PMID:2898716]

161. Hawkins KN, Morelli M, Gulya K, Chang KJ and Yamamura HI. (1987) Autoradiographic localization of [3H] [MePhe3,D-Pro4]morphiceptin ([3H]PL017) to mu opioid receptors in rat brain. Eur J Pharmacol 133: 351-2 [PMID:3030778]

162. Henriksen G, Platzer S, Marton J, Hauser A, Berthele A, Schwaiger M, Marinelli L, Lavecchia A, Novellino E and Wester HJ. (2005) Syntheses, biological evaluation, and molecular modeling of 18F-labeled 4-anilidopiperidines as mu-opioid receptor imaging agents. J Med Chem 48: 772032 [PMID:16302812]

163. Henry DJ, Grandy DK, Lester HA, Davidson N and Chavkin C. (1995) Kappa-opioid receptors couple to inwardly rectifying potassium channels when coexpressed by Xenopus oocytes. $\mathrm{Mol}$ Pharmacol 47: 551-7 [PMID:7700253]

164. Herlitze S, Garcia DE, Mackie K, Hille B, Scheuer T and Catterall WA. (1996) Modulation of $\mathrm{Ca} 2+$ channels by G-protein beta gamma subunits. Nature 380: 258-62 [PMID:8637576]

165. Hiller JM, Fan LQ and Simon EJ. (1996) Autoradiographic comparison of [3H]DPDPE and [3H]DSLET binding: evidence for distinct delta 1 and delta 2 opioid receptor populations in rat brain. Brain Res 719: 85-95 [PMID:8782867]

166. Hjorth SA, Thirstrup K and Schwartz TW. (1996) Radioligand-dependent discrepancy in agonist affinities enhanced by mutations in the kappa-opioid receptor. Mol Pharmacol 50: 977-84 [PMID:8863844] 
167. Ho M, Corbett AD and McKnight AT. (2000) Characterization of the ORL(1) receptor on adrenergic nerves in the rat anococcygeus muscle. Br J Pharmacol 131: 349-55 [PMID:10991930]

168. Ho MK, New DC and Wong YH. (2002) Co-expressions of different opioid receptor types differentially modulate their signaling via G(16). Neurosignals 11: 115-22 [PMID:12077485]

169. Horan P, de Costa BR, Rice KC and Porreca F. (1991) Differential antagonism of U69,593- and bremazocine-induced antinociception by (-)-UPHIT: evidence of kappa opioid receptor multiplicity in mice. J Pharmacol Exp Ther 257: 1154-61 [PMID:1646325]

170. Horan PJ, de Costa BR, Rice K, Haaseth RC, Hruby VJ and Porreca F. (1993) Differential antagonism of bremazocine- and U69,593-induced antinociception by quadazocine: further functional evidence of opioid kappa receptor multiplicity in the mouse. J Pharmacol Exp Ther 266: 926-33 [PMID:8394923]

171. Horan PJ and Porreca F. (1993) Lack of cross-tolerance between U69,593 and bremazocine suggests kappa-opioid receptor multiplicity in mice. Eur J Pharmacol 239: 93-8 [PMID:8223918]

172. Huang P, Steplock D, Weinman EJ, Hall RA, Ding Z, Li J, Wang Y and Liu-Chen LY. (2004) kappa Opioid receptor interacts with $\mathrm{Na}(+) / \mathrm{H}(+)$-exchanger regulatory factor-1/Ezrin-radixin-moesinbinding phosphoprotein-50 (NHERF-1/EBP50) to stimulate $\mathrm{Na}(+) / \mathrm{H}(+)$ exchange independent of G(i)/G(o) proteins. J Biol Chem 279: 25002-9 [PMID:15070904]

173. Hughes J, Kosterlitz HW and Leslie FM. (1975) Effect of morphine on adrenergic transmission in the mouse vas deferens. Assessment of agonist and antogonist potencies of narcotic analgesics. Br J Pharmacol 53: 371-81 [PMID:236796]

174. Hughes J, Smith TW, Kosterlitz HW, Fothergill LA, Morgan BA and Morris HR. (1975) Identification of two related pentapeptides from the brain with potent opiate agonist activity. Nature 258: 577-80 [PMID:1207728]

175. Hunter JC, Leighton GE, Meecham KG, Boyle SJ, Horwell DC, Rees DC and Hughes J. (1990) CI977, a novel and selective agonist for the kappa-opioid receptor. Br J Pharmacol 101: 183-9 [PMID:2178014]

176. Husbands SM and Lewis JW. (1995) Morphinan cyclic imines and pyrrolidines containing a constrained phenyl group: high affinity opioid agonists Bioorg Med Chem Lett 5: 2969-2974

177. Hutcheson DM, Matthes HW, Valjent E, Sánchez-Blázquez P, Rodríguez-Díaz M, Garzón J, Kieffer BL and Maldonado R. (2001) Lack of dependence and rewarding effects of deltorphin II in mu-opioid receptor-deficient mice. Eur J Neurosci 13: 153-61 [PMID:11135013]

178. Inagaki M, Kume M, Tamura $Y$, Hara S, Goto Y, Haga N, Hasegawa T, Nakamura T, Koike K and Oonishi S et al.. (2019) Discovery of naldemedine: A potent and orally available opioid receptor antagonist for treatment of opioid-induced adverse effects. Bioorg Med Chem Lett 29: 73-77 [PMID:30446313]

179. Inoue M, Kawashima $T$, Takeshima H, Calo G, Inoue A, Nakata $Y$ and Ueda H. (2003) In vivo pain-inhibitory role of nociceptin/orphanin FQ in spinal cord. J Pharmacol Exp Ther 305: 495501 [PMID:12606680]

180. Inoue M, Kobayashi M, Kozaki S, Zimmer A and Ueda H. (1998) Nociceptin/orphanin FQinduced nociceptive responses through substance $P$ release from peripheral nerve endings in mice. Proc Natl Acad Sci USA 95: 10949-53 [PMID:9724810]

181. Inoue M, Shimohira I, Yoshida A, Zimmer A, Takeshima H, Sakurada T and Ueda H. (1999) Dose-related opposite modulation by nociceptin/orphanin FQ of substance P nociception in the nociceptors and spinal cord. J Pharmacol Exp Ther 291: 308-13 [PMID:10490918]

182. Itoh K, Konya H, Takai E, Masuda H and Nagai K. (1999) Modification of acetylcholine release by nociceptin in conscious rat striatum. Brain Res 845: 242-5 [PMID:10536205]

183. Jamot L, Matthes HW, Simonin F, Kieffer BL and Roder JC. (2003) Differential involvement of the mu and kappa opioid receptors in spatial learning. Genes Brain Behav 2: 80-92 [PMID:12884965]

184. Jang CG, Lee SY, Yoo JH, Yan JJ, Song DK, Loh HH and Ho IK. (2003) Impaired water maze learning performance in mu-opioid receptor knockout mice. Brain Res Mol Brain Res 117: 68-72 [PMID:14499482]

185. Jenck F, Moreau JL, Martin JR, Kilpatrick GJ, Reinscheid RK, Monsma Jr FJ, Nothacker HP and Civelli O. (1997) Orphanin FQ acts as an anxiolytic to attenuate behavioral responses to stress. Proc Natl Acad Sci USA 94: 14854-8 [PMID:9405703]

186. Jenck F, Wichmann J, Dautzenberg FM, Moreau JL, Ouagazzal AM, Martin JR, Lundstrom K, Cesura AM, Poli SM and Roever S et al.. (2000) A synthetic agonist at the orphanin FQ/nociceptin receptor ORL1: anxiolytic profile in the rat. Proc Natl Acad Sci USA 97: 4938-43 [PMID:10758169]

187. Jones RM and Portoghese PS. (2000) 5'-Guanidinonaltrindole, a highly selective and potent kappa-opioid receptor antagonist. Eur J Pharmacol 396: 49-52 [PMID:10822054]

188. Jongkamonwiwat N, Phansuwan-Pujito P, Sarapoke P, Chetsawang B, Casalotti SO, Forge A, Dodson H and Govitrapong P. (2003) The presence of opioid receptors in rat inner ear. Hear Res 181: 85-93 [PMID:12855366] 
189. Jordan BA and Devi LA. (1999) G-protein-coupled receptor heterodimerization modulates receptor function. Nature 399: 697-700 [PMID:10385123]

190. Kam AY, Chan AS and Wong YH. (2003) Rac and Cdc42-dependent regulation of c-Jun Nterminal kinases by the delta-opioid receptor. J Neurochem 84: 503-13 [PMID:12558970]

191. Kam AY, Chan AS and Wong YH. (2004) Phosphatidylinositol-3 kinase is distinctively required for mu-, but not kappa-opioid receptor-induced activation of c-Jun $\mathrm{N}$-terminal kinase. $J$ Neurochem 89: 391-402 [PMID:15056283]

192. Kaneko T, Minami M, Satoh M and Mizuno N. (1995) Immunocytochemical localization of muopioid receptor in the rat caudate-putamen. Neurosci Lett 184: 149-52 [PMID:7715834]

193. Kapusta DR, Burmeister MA, Calo' G, Guerrini R, Gottlieb HB and Kenigs VA. (2005) Functional selectivity of nociceptin/orphanin FQ peptide receptor partial agonists on cardiovascular and renal function. J Pharmacol Exp Ther 314: 643-51 [PMID:15855356]

194. Kapusta DR and Kenigs VA. (1999) Cardiovascular and renal responses produced by central orphanin FQ/nociceptin occur independent of renal nerves. Am J Physiol 277: R987-95 [PMID:10516236]

195. Kathmann M, Flau K, Redmer A, Tränkle C and Schlicker E. (2006) Cannabidiol is an allosteric modulator at mu- and delta-opioid receptors. Naunyn Schmiedebergs Arch Pharmacol 372: 35461 [PMID:16489449]

196. Kawamoto H, Ozaki S, Itoh Y, Miyaji M, Arai S, Nakashima H, Kato T, Ohta H and Iwasawa Y. (1999) Discovery of the first potent and selective small molecule opioid receptor-like (ORL1) antagonist: 1-[(3R,4R)-1-cyclooctylmethyl-3- hydroxymethyl-4-piperidyl]-3-ethyl-1, 3-dihydro-2Hbenzimidazol-2-one (J-113397). J Med Chem 42: 5061-3 [PMID:10602690]

197. Kelly E, Mundell SJ, Sava A, Roth AL, Felici A, Maltby K, Nathan PJ, Bullmore ET and Henderson G. (2015) The opioid receptor pharmacology of GSK1521498 compared to other ligands with differential effects on compulsive reward-related behaviours. Psychopharmacology (Berl.) 232: 305-14 [PMID:24973897]

198. Khroyan TV, Polgar WE, Cami-Kobeci G, Husbands SM, Zaveri NT and Toll L. (2011) The first universal opioid ligand, (2S)-2-[(5R,6R,7R,14S)-N-cyclopropylmethyl-4,5-epoxy-6,14-ethano-3hydroxy-6-methoxymorphinan-7-yl]-3,3-dimethylpentan-2-ol (BU08028): characterization of the in vitro profile and in vivo behavioral effects in mouse models of acute pain and cocaine-induced reward. J Pharmacol Exp Ther 336: 952-61 [PMID:21177476]

199. Kieffer BL. (1995) Recent advances in molecular recognition and signal transduction of active peptides: receptors for opioid peptides. Cell Mol Neurobiol 15: 615-35 [PMID:8719033]

200. Kieffer BL, Befort K, Gaveriaux-Ruff C and Hirth CG. (1992) Delta-opioid receptor: isolation of a cDNA by expression cloning and pharmacological characerization. Proc Natl Acad Sci USA 89: 12048-12052 [PMID:1334555]

201. Kitchen I, Slowe SJ, Matthes HW and Kieffer B. (1997) Quantitative autoradiographic mapping of mu-, delta- and kappa-opioid receptors in knockout mice lacking the mu-opioid receptor gene. Brain Res 778: 73-88 [PMID:9462879]

202. Knapp RJ, Malatynska E, Fang L, Li X, Babin E, Nguyen M, Santoro G, Varga EV, Hruby VJ and Roeske WR et al.. (1994) Identification of a human delta opioid receptor: cloning and expression. Life Sci 54: PL463-9 [PMID:8201839]

203. Koch T, Brandenburg LO, Schulz S, Liang Y, Klein J and Hollt V. (2003) ADP-ribosylation factordependent phospholipase D2 activation is required for agonist-induced mu-opioid receptor endocytosis. J Biol Chem 278: 9979-9985 [PMID:12519790]

204. Koch T, Kroslak T, Averbeck M, Mayer P, Schröder H, Raulf E and Höllt V. (2000) Allelic variation S268P of the human mu-opioid receptor affects both desensitization and G protein coupling. Mol Pharmacol 58: 328-34 [PMID:10908300]

205. Koch T, Schulz S, Pfeiffer M, Klutzny M, Schröder H, Kahl E and Höllt V. (2001) C-terminal splice variants of the mouse mu-opioid receptor differ in morphine-induced internalization and receptor resensitization. J Biol Chem 276: 31408-14 [PMID:11359768]

206. Koch T, Schulz S, Schröder H, Wolf R, Raulf E and Höllt V. (1998) Carboxyl-terminal splicing of the rat mu opioid receptor modulates agonist-mediated internalization and receptor resensitization. J Biol Chem 273: 13652-7 [PMID:9593704]

207. Koch T, Widera A, Bartzsch K, Schulz S, Brandenburg LO, Wundrack N, Beyer A, Grecksch G and Höllt V. (2005) Receptor endocytosis counteracts the development of opioid tolerance. Mol Pharmacol 67: 280-287 [PMID:15475572]

208. Koehl A, Hu H, Maeda S, Zhang Y, Qu Q, Paggi JM, Latorraca NR, Hilger D, Dawson R and Matile $\mathrm{H}$ et al.. (2018) Structure of the $\mu$-opioid receptor- $\mathrm{G}_{\mathrm{i}}$ protein complex. Nature 558: 547552 [PMID:29899455]

209. Konkoy CS and Childers SR. (1993) Relationship between kappa 1 opioid receptor binding and inhibition of adenylyl cyclase in guinea pig brain membranes. Biochem Pharmacol 45: 207-16 [PMID:8381004]

210. Konya H, Masuda H, Itoh K, Nagai K, Kakishita E and Matsuoka A. (1998) Modification of dopamine release by nociceptin in conscious rat striatum. Brain Res 788: 341-4 
[PMID:9555088]

211. Kozak CA, Filie J, Adamson MC, Chen Y and Yu L. (1994) Murine chromosomal location of the mu and kappa opioid receptor genes. Genomics 21: 659-61 [PMID:7959748]

212. Kreek MJ, Bart G, Lilly C, LaForge KS and Nielsen DA. (2005) Pharmacogenetics and human molecular genetics of opiate and cocaine addictions and their treatments. Pharmacol Rev 57: 126 [PMID:15734726]

213. Kreek MJ, Schluger J, Borg L, Gunduz M and Ho A. (1999) Dynorphin A1-13 causes elevation of serum levels of prolactin through an opioid receptor mechanism in humans: gender differences and implications for modulation of dopaminergic tone in the treatment of addictions. $J$ Pharmacol Exp Ther 288: 260-9 [PMID:9862779]

214. Krulich L, Koenig JI, Conway S, McCann SM and Mayfield MA. (1986) Opioid kappa receptors and the secretion of prolactin (PRL) and growth hormone (GH) in the rat. II. GH and PRL release-inhibiting effects of the opioid kappa receptor agonists bremazocine and U-50,488. Neuroendocrinology 42: 82-87 [PMID:3001566]

215. Kumar V, Guo D, Daubert JD, Cassel JA, DeHaven RN, Mansson E, DeHaven-Hudkins DL and Maycock AL. (2005) Amino acid conjugates as kappa opioid receptor agonists. Bioorg Med Chem Lett 15: 1279-82 [PMID:15713370]

216. Kumar V, Guo D, Marella M, Cassel JA, Dehaven RN, Daubert JD and Mansson E. (2008) Use of receptor chimeras to identify small molecules with high affinity for the dynorphin A binding domain of the kappa opioid receptor. Bioorg Med Chem Lett 18: 3667-71 [PMID:18487043]

217. Kuszak AJ, Pitchiaya S, Anand JP, Mosberg HI, Walter NG and Sunahara RK. (2009) Purification and functional reconstitution of monomeric mu-opioid receptors: allosteric modulation of agonist binding by Gi2. J Biol Chem 284: 26732-41 [PMID:19542234]

218. Kvam TM, Baar C, Rakvåg TT, Kaasa S, Krokan HE and Skorpen F. (2004) Genetic analysis of the murine mu opioid receptor: increased complexity of Oprm gene splicing. J Mol Med 82: 2505 [PMID:14991152]

219. Lahti RA, Mickelson MM, McCall JM and Von Voigtlander PF. (1985) [3H]U-69593 a highly selective ligand for the opioid kappa receptor. Eur J Pharmacol 109: 281-4 [PMID:2986999]

220. Lai HW, Minami M, Satoh M and Wong YH. (1995) Gz coupling to the rat kappa-opioid receptor. FEBS Lett 360: 97-9 [PMID:7875310]

221. Lambert DG. (2008) The nociceptin/orphanin FQ receptor: a target with broad therapeutic potential. Nat Rev Drug Discov 7: 694-710 [PMID:18670432]

222. Law PY, Hom DS and Loh HH. (1985) Multiple affinity states of opiate receptor in neuroblastoma x glioma NG108-15 hybrid cells. Opiate agonist association rate is a function of receptor occupancy. J Biol Chem 260: 3561-9 [PMID:2982865]

223. Law PY, Wong YH and Loh HH. (2000) Molecular mechanisms and regulation of opioid receptor signaling. Annu Rev Pharmacol Toxicol 40: 389-430 [PMID:10836142]

224. Lawrence DM and Bidlack JM. (1993) The kappa opioid receptor expressed on the mouse R1.1 thymoma cell line is coupled to adenylyl cyclase through a pertussis toxin-sensitive guanine nucleotide-binding regulatory protein. J Pharmacol Exp Ther 266: 1678-83 [PMID:8103800]

225. Le Bourdonnec B, Barker WM, Belanger S, Wiant DD, Conway-James NC, Cassel JA, O'Neill TJ, Little PJ, DeHaven RN and DeHaven-Hudkins DL et al.. (2008) Novel trans-3,4-dimethyl-4-(3hydroxyphenyl)piperidines as mu opioid receptor antagonists with improved opioid receptor selectivity profiles. Bioorg Med Chem Lett 18: 2006-12 [PMID:18313920]

226. Le Bourdonnec B, Windh RT, Ajello CW, Leister LK, Gu M, Chu GH, Tuthill PA, Barker WM, Koblish M and Wiant DD et al.. (2008) Potent, orally bioavailable delta opioid receptor agonists for the treatment of pain: discovery of N,N-diethyl-4-(5-hydroxyspiro[chromene-2,4'piperidine]-4-yl)benzamide (ADL5859). J Med Chem 51: 5893-6 [PMID:18788723]

227. Le Bourdonnec B, Windh RT, Leister LK, Zhou QJ, Ajello CW, Gu M, Chu GH, Tuthill PA, Barker WM and Koblish M et al.. (2009) Spirocyclic delta opioid receptor agonists for the treatment of pain: discovery of N,N-diethyl-3-hydroxy-4-(spiro[chromene-2,4'-piperidine]-4-yl) benzamide (ADL5747). J Med Chem 52: 5685-702 [PMID:19694468]

228. Le Merrer J, Plaza-Zabala A, Del Boca C, Matifas A, Maldonado R and Kieffer BL. (2011) Deletion of the $\delta$ opioid receptor gene impairs place conditioning but preserves morphine reinforcement. Biol Psychiatry 69: 700-3 [PMID:21168121]

229. Le Merrer J, Rezai X, Scherrer G, Becker JA and Kieffer BL. (2013) Impaired hippocampusdependent and facilitated striatum-dependent behaviors in mice lacking the $\delta$ opioid receptor. Neuropsychopharmacology 38: 1050-9 [PMID:23303070]

230. Leander JD. (1984) Kappa opioid agonists and antagonists: effects on drinking and urinary output. Appetite 5: 7-14 [PMID:6091543]

231. Lee JW, Joshi S, Chan JS and Wong YH. (1998) Differential coupling of mu-, delta-, and kappaopioid receptors to G alpha16-mediated stimulation of phospholipase C. J Neurochem 70: 220311 [PMID:9572309]

232. Lefkowitz RJ and Shenoy SK. (2005) Transduction of receptor signals by beta-arrestins. Science 308: 512-517 [PMID:15845844] 
233. Lei W, Vekariya RH, Ananthan S and Streicher JM. (2020) A Novel Mu-Delta Opioid Agonist Demonstrates Enhanced Efficacy With Reduced Tolerance and Dependence in Mouse Neuropathic Pain Models. J Pain 21: 146-160 [PMID:31201990]

234. Lever JR and Scheffel U. (1998) Selective in vivo binding of [3H]naltriben to delta-opioid receptors in mouse brain. Eur J Pharmacol 350: 335-44 [PMID:9696425]

235. Li JL, Ding YQ, Li YQ, Li JS, Nomura S, Kaneko T and Mizuno N. (1998) Immunocytochemical localization of mu-opioid receptor in primary afferent neurons containing substance $\mathrm{P}$ or calcitonin gene-related peptide. A light and electron microscope study in the rat. Brain Res 794: 347-52 [PMID:9622672]

236. Li LY and Chang KJ. (1996) The stimulatory effect of opioids on mitogen-activated protein kinase in Chinese hamster ovary cells transfected to express mu-opioid receptors. Mol Pharmacol 50: 599-602 [PMID:8794899]

237. Li S, Zhu J, Chen C, Chen YW, Deriel JK, Ashby B and Liu-Chen LY. (1993) Molecular cloning and expression of a rat kappa opioid receptor. Biochem J 295 ( Pt 3): 629-33 [PMID:8240268]

238. Linz K, Christoph T, Tzschentke TM, Koch T, Schiene K, Gautrois M, Schröder W, Kögel BY, Beier H and Englberger W et al.. (2014) Cebranopadol: a novel potent analgesic nociceptin/orphanin FQ peptide and opioid receptor agonist. J Pharmacol Exp Ther 349: 535-48 [PMID:24713140]

239. Liu HC, Lu S, Augustin LB, Felsheim RF, Chen HC, Loh HH and Wei LN. (1995) Cloning and promoter mapping of mouse kappa opioid receptor gene. Biochem Biophys Res Commun 209: 639-647 [PMID:7733933]

240. Liu JG and Prather PL. (2002) Chronic agonist treatment converts antagonists into inverse agonists at delta-opioid receptors. J Pharmacol Exp Ther 302: 1070-9 [PMID:12183665]

241. Livingston KE, Stanczyk MA, Burford NT, Alt A, Canals M and Traynor JR. (2018) Pharmacologic Evidence for a Putative Conserved Allosteric Site on Opioid Receptors. Mol Pharmacol 93: 157167 [PMID:29233847]

242. Lo RK and Wong YH. (2004) Signal transducer and activator of transcription 3 activation by the delta-opioid receptor via Galpha14 involves multiple intermediates. Mol Pharmacol 65: 1427-39 [PMID:15155836]

243. Loh HH, Liu HC, Cavalli A, Yang W, Chen YF and Wei LN. (1998) mu Opioid receptor knockout in mice: effects on ligand-induced analgesia and morphine lethality. Brain Res Mol Brain Res 54: 321-6 [PMID:9555078]

244. Lord JA, Waterfield AA, Hughes J and Kosterlitz HW. (1977) Endogenous opioid peptides: multiple agonists and receptors. Nature 267: 495-9 [PMID:195217]

245. Lupica CR. (1995) Delta and mu enkephalins inhibit spontaneous GABA-mediated IPSCs via a cyclic AMP-independent mechanism in the rat hippocampus. J Neurosci 15: 737-49 [PMID:7823176]

246. Lötsch J and Geisslinger G. (2005) Are mu-opioid receptor polymorphisms important for clinical opioid therapy? Trends Mol Med 11: 82-9 [PMID:15694871]

247. Magnan J, Paterson SJ, Tavani A and Kosterlitz HW. (1982) The binding spectrum of narcotic analgesic drugs with different agonist and antagonist properties. Naunyn Schmiedebergs Arch Pharmacol 319: 197-205 [PMID:6125900]

248. Maisonneuve IM, Archer S and Glick SD. (1994) U50,488, a kappa opioid receptor agonist, attenuates cocaine-induced increases in extracellular dopamine in the nucleus accumbens of rats. Neurosci Lett 181: 57-60 [PMID:7898771]

249. Majumdar S, Burgman M, Haselton N, Grinnell S, Ocampo J, Pasternak AR and Pasternak GW. (2011) Generation of novel radiolabeled opiates through site-selective iodination. Bioorg Med Chem Lett 21: 4001-4 [PMID:21621410]

250. Malfacini D, Ambrosio C, Gro' MC, Sbraccia M, Trapella C, Guerrini R, Bonora M, Pinton P, Costa T and Calo' G. (2015) Pharmacological Profile of Nociceptin/Orphanin FQ Receptors Interacting with G-Proteins and $\beta$-Arrestins 2. PLoS ONE 10: e0132865 [PMID:26248189]

251. Manabe T, Noda Y, Mamiya T, Katagiri H, Houtani T, Nishi M, Noda T, Takahashi T, Sugimoto T and Nabeshima T et al.. (1998) Facilitation of long-term potentiation and memory in mice lacking nociceptin receptors. Nature 394: 577-81 [PMID:9707118]

252. Manallack DT, Beart PM and Gundlach AL. (1986) Psychotomimetic sigma-opiates and PCP. Trends Pharmacol Sci 7: 448-451

253. Mandyam CD, Altememi GF and Standifer KM. (2000) beta-Funaltrexamine inactivates ORL1 receptors in BE(2)-C human neuroblastoma cells. Eur J Pharmacol 402: R1-37 [PMID:10940375]

254. Manglik A, Kruse AC, Kobilka TS, Thian FS, Mathiesen JM, Sunahara RK, Pardo L, Weis WI, Kobilka BK and Granier S. (2012) Crystal structure of the $\mu$-opioid receptor bound to a morphinan antagonist. Nature 485: 321-6 [PMID:22437502]

255. Manglik A, Lin H, Aryal DK, McCorvy JD, Dengler D, Corder G, Levit A, Kling RC, Bernat V and Hübner H et al.. (2016) Structure-based discovery of opioid analgesics with reduced side effects. Nature 537: 185-190 [PMID:27533032]

256. Mangoura D. (1997) mu-Opioids activate tyrosine kinase focal adhesion kinase and regulate 
cortical cytoskeleton proteins cortactin and vinculin in chick embryonic neurons. J Neurosci Res 50: 391-401 [PMID:9364324]

257. Mansour A, Fox CA, Akil H and Watson SJ. (1995) Opioid-receptor mRNA expression in the rat CNS: anatomical and functional implications. Trends Neurosci 18: 22-29 [PMID:7535487]

258. Mansour A, Fox CA, Burke S, Meng F, Thompson RC, Akil H and Watson SJ. (1994) Mu, delta, and kappa opioid receptor mRNA expression in the rat CNS: an in situ hybridization study. $J$ Comp Neurol 350: 412-438 [PMID:7884049]

259. Mansour A, Fox CA, Thompson RC, Akil H and Watson SJ. (1994) mu-Opioid receptor mRNA expression in the rat CNS: comparison to mu-receptor binding. Brain Res 643: 245-65 [PMID:8032920]

260. Mansour A, Khachaturian H, Lewis ME, Akil H and Watson SJ. (1987) Autoradiographic differentiation of mu, delta, and kappa opioid receptors in the rat forebrain and midbrain. $J$ Neurosci 7: 2445-64 [PMID:3039080]

261. Mansour A, Thompson RC, Akil H and Watson SJ. (1993) Delta opioid receptor mRNA distribution in the brain: comparison to delta receptor binding and proenkephalin mRNA. $J$ Chem Neuroanat 6: 351-362 [PMID:8142072]

262. Mansson E, Bare L and Yang D. (1994) Isolation of a human kappa opioid receptor cDNA from placenta. Biochem Biophys Res Commun 202: 1431-7 [PMID:8060324]

263. Marie N, Landemore G, Debout C, Jauzac P and Allouche S. (2003) Pharmacological characterization of AR-M1000390 at human delta opioid receptors. Life Sci 73: 1691-704 [PMID:12875901]

264. Marti M, Mela F, Budri M, Volta M, Malfacini D, Molinari S, Zaveri NT, Ronzoni S, Petrillo P and Calò G et al.. (2013) Acute and chronic antiparkinsonian effects of the novel nociceptin/orphanin FQ receptor antagonist NiK-21273 in comparison with SB-612111. Br J Pharmacol 168: 863-79 [PMID:22994368]

265. Marti M, Mela F, Fantin M, Zucchini S, Brown JM, Witta J, Di Benedetto M, Buzas B, Reinscheid RK and Salvadori S et al.. (2005) Blockade of nociceptin/orphanin FQ transmission attenuates symptoms and neurodegeneration associated with Parkinson's disease. J Neurosci 25: 9591-601 [PMID:16237164]

266. Marti M, Mela F, Veronesi C, Guerrini R, Salvadori S, Federici M, Mercuri NB, Rizzi A, Franchi $\mathrm{G}$ and Beani L et al.. (2004) Blockade of nociceptin/orphanin FQ receptor signaling in rat substantia nigra pars reticulata stimulates nigrostriatal dopaminergic transmission and motor behavior. J Neurosci 24: 6659-66 [PMID:15282268]

267. Marti M, Stocchi S, Paganini F, Mela F, De Risi C, Calo' G, Guerrini R, Barnes TA, Lambert DG and Beani L et al.. (2003) Pharmacological profiles of presynaptic nociceptin/orphanin FQ receptors modulating 5-hydroxytryptamine and noradrenaline release in the rat neocortex. $\mathrm{Br} \mathrm{J}$ Pharmacol 138: 91-8 [PMID:12522077]

268. Martin M, Matifas A, Maldonado R and Kieffer BL. (2003) Acute antinociceptive responses in single and combinatorial opioid receptor knockout mice: distinct mu, delta and kappa tones. Eur J Neurosci 17: 701-8 [PMID:12603260]

269. Martin WR, Eades CG, Thompson JA, Huppler RE and Gilbert PE. (1976) The effects of morphine- and nalorphine- like drugs in the nondependent and morphine-dependent chronic spinal dog. J Pharmacol Exp Ther 197: 517-32 [PMID:945347]

270. Matthes HW, Maldonado R, Simonin F, Valverde O, Slowe S, Kitchen I, Befort K, Dierich A, Le Meur M and Dollé P et al.. (1996) Loss of morphine-induced analgesia, reward effect and withdrawal symptoms in mice lacking the mu-opioid-receptor gene. Nature 383: 819-23 [PMID:8893006]

271. Matthies H, Schroeder H, Becker A, Loh H, Höllt V and Krug M. (2000) Lack of expression of long-term potentiation in the dentate gyrus but not in the CA1 region of the hippocampus of muopioid receptor-deficient mice. Neuropharmacology 39: 952-60 [PMID:10727705]

272. Mayer P and Höllt V. (2005) Genetic disposition to addictive disorders--current knowledge and future perspectives. Curr Opin Pharmacol 5: 4-8 [PMID:15661619]

273. Mayer P, Schulzeck S, Kraus J, Zimprich A and Höllt V. (1996) Promoter region and alternatively spliced exons of the rat mu-opioid receptor gene. J Neurochem 66: 2272-8 [PMID:8632148]

274. McCarthy L, Szabo I, Nitsche JF, Pintar JE and Rogers TJ. (2001) Expression of functional muopioid receptors during T cell development. J Neuroimmunol 114: 173-80 [PMID:11240029]

275. McCarthy L, Wetzel M, Sliker JK, Eisenstein TK and Rogers TJ. (2001) Opioids, opioid receptors, and the immune response. Drug Alcohol Depend 62: 111-23 [PMID:11245967]

276. McDonald J, Barnes TA, Okawa H, Williams J, Calo' G, Rowbotham DJ and Lambert DG. (2003) Partial agonist behaviour depends upon the level of nociceptin/orphanin FQ receptor expression: studies using the ecdysone-inducible mammalian expression system. Br J Pharmacol 140: 61-70 [PMID:12967935]

277. McLeod RL, Tulshian DB, Bolser DC, Varty GB, Baptista M, Fernandez X, Parra LE, Zimmer JC, Erickson CH and Ho GD et al.. (2010) Pharmacological profile of the NOP agonist and cough suppressing agent SCH 486757 (8-[Bis(2-Chlorophenyl)Methyl]-3-(2-Pyrimidinyl)-8- 
Azabicyclo[3.2.1] Octan-3-Ol) in preclinical models. Eur J Pharmacol 630: 112-20 [PMID:20006596]

278. Meng F, Xie GX, Thompson RC, Mansour A, Goldstein A, Watson SJ and Akil H. (1993) Cloning and pharmacological characterization of a rat kappa opioid receptor. Proc Natl Acad Sci USA 90: 9954-8 [PMID:8234341]

279. Mennicken F, Zhang J, Hoffert C, Ahmad S, Beaudet A and O'Donnell D. (2003) Phylogenetic changes in the expression of delta opioid receptors in spinal cord and dorsal root ganglia. $J$ Comp Neurol 465: 349-60 [PMID:12966560]

280. Menzies JR, Glen T, Davies MR, Paterson SJ and Corbett AD. (1999) In vitro agonist effects of nociceptin and [Phe(1)psi(CH(2)-NH)Gly(2)]nociceptin(1-13)NH(2) in the mouse and rat colon and the mouse vas deferens. Eur J Pharmacol 385: 217-23 [PMID:10607879]

281. Meunier J, Mouledous L and Topham CM. (2000) The nociceptin (ORL1) receptor: molecular cloning and functional architecture. Peptides 21: 893-900 [PMID:10998522]

282. Meunier J-C, Mollereau C, Toll L, Suaudeau C, Moisand C, Alvinerie P, Butour JL, Guillemot JC, Ferrara P and Monsarrat B et al.. (1995) Isolation and structure of the endogenous agonist of opioid receptor-like ORL-1 receptor. Nature 377: 532-535 [PMID:7566152]

283. Min BH, Augustin LB, Felsheim RF, Fuchs JA and Loh HH. (1994) Genomic structure analysis of promoter sequence of a mouse mu opioid receptor gene. Proc Natl Acad Sci USA 91: 9081-5 [PMID:8090773]

284. Minami M, Onogi T, Toya T, Katao Y, Hosoi Y, Maekawa K, Katsumata S, Yabuuchi K and Satoh M. (1994) Molecular cloning and in situ hybridization histochemistry for rat mu-opioid receptor. Neurosci Res 18: 315-322 [PMID:8190373]

285. Minami M, Toya T, Katao Y, Maekawa K, Nakamura S, Onogi T, Kaneko S and Satoh M. (1993) Cloning and expression of a cDNA for the rat kappa-opioid receptor. FEBS Lett 329: 291-5 [PMID:8103466]

286. Mitrovic I, Margeta-Mitrovic M, Bader S, Stoffel M, Jan LY and Basbaum AI. (2003) Contribution of GIRK2-mediated postsynaptic signaling to opiate and alpha 2-adrenergic analgesia and analgesic sex differences. Proc Natl Acad Sci USA 100: 271-6 [PMID:12496346]

287. Miyazaki T, Choi IY, Rubas W, Anand NK, Ali C, Evans J, Gursahani H, Hennessy M, Kim G and McWeeney D et al.. (2017) NKTR-181: A Novel Mu-Opioid Analgesic with Inherently Low Abuse Potential. J Pharmacol Exp Ther 363: 104-113 [PMID:28778859]

288. Mogil JS, Grisel JE, Zhangs G, Belknap JK and Grandy DK. (1996) Functional antagonism of mu-, delta- and kappa-opioid antinociception by orphanin FQ. Neurosci Lett 214: 131-4 [PMID:8878101]

289. Mogil JS and Pasternak GW. (2001) The molecular and behavioral pharmacology of the orphanin FQ/nociceptin peptide and receptor family. Pharmacol Rev 53: 381-415 [PMID:11546835]

290. Moises HC, Rusin KI and Macdonald RL. (1994) Mu- and kappa-opioid receptors selectively reduce the same transient components of high-threshold calcium current in rat dorsal root ganglion sensory neurons. J Neurosci 14: 5903-16 [PMID:7931552]

291. Moles A, Kieffer BL and D'Amato FR. (2004) Deficit in attachment behavior in mice lacking the mu-opioid receptor gene. Science 304: 1983-6 [PMID:15218152]

292. Mollereau C, Moisand C, Butour JL, Parmentier M and Meunier JC. (1996) Replacement of Gln280 by His in TM6 of the human ORL1 receptor increases affinity but reduces intrinsic activity of opioids. FEBS Lett 395: 17-21 [PMID:8849681]

293. Mollereau C and Mouledous L. (2000) Tissue distribution of the opioid receptor-like (ORL1) receptor. Peptides 21: 907-17 [PMID:10998524]

294. Mollereau C, Parmentier M, Mailleux P, Butour JL, Moisand C, Chalon P, Caput D, Vassart G and Meunier JC. (1994) ORL1, a novel member of the opioid receptor family. Cloning, functional expression and localization. FEBS Lett 341: 33-8 [PMID:8137918]

295. Mollereau C, Simons MJ, Soularue P, Liners F, Vassart G, Meunier JC and Parmentier M. (1996) Structure, tissue distribution, and chromosomal localization of the prepronociceptin gene. Proc Natl Acad Sci USA 93: 8666-70 [PMID:8710928]

296. Morikawa H, Fukuda K, Kato S, Mori K and Higashida H. (1995) Coupling of the cloned muopioid receptor with the omega-conotoxin-sensitive Ca2+ current in NG108-15 cells. J Neurochem 65: 1403-6 [PMID:7643119]

297. Morinville A, Cahill CM, Esdaile MJ, Aibak H, Collier B, Kieffer BL and Beaudet A. (2003) Regulation of delta-opioid receptor trafficking via mu-opioid receptor stimulation: evidence from mu-opioid receptor knock-out mice. J Neurosci 23: 4888-98 [PMID:12832511]

298. Morinville A, Cahill CM, Kieffer B, Collier B and Beaudet A. (2004) Mu-opioid receptor knockout prevents changes in delta-opioid receptor trafficking induced by chronic inflammatory pain. Pain 109: 266-73 [PMID:15157687]

299. Moriwaki A, Wang JB, Svingos A, van Bockstaele E, Cheng P, Pickel V and Uhl GR. (1996) mu Opiate receptor immunoreactivity in rat central nervous system. Neurochem Res 21: 1315-31 [PMID:8947922]

300. Morley JE, Levine AS, Kneip J, Grace M, Zeugner H and Shearman GT. (1985) The kappa opioid 
receptor and food intake. Eur J Pharmacol 112: 17-25 [PMID:2990965]

301. Mosberg HI, Hurst R, Hruby VJ, Gee K, Yamamura HI, Galligan JJ and Burks TF. (1983) Bispenicillamine enkephalins possess highly improved specificity toward delta opioid receptors. Proc Natl Acad Sci USA 80: 5871-4 [PMID:6310598]

302. MRC. AZD7268 6-Opioid receptor agonist.

303. Mrkusich EM, Kivell BM, Miller JH and Day DJ. (2004) Abundant expression of mu and delta opioid receptor mRNA and protein in the cerebellum of the fetal, neonatal, and adult rat. Brain Res Dev Brain Res 148: 213-222 [PMID:14766199]

304. Munro TA, Huang XP, Inglese C, Perrone MG, Van't Veer A, Carroll FI, Béguin C, Carlezon Jr WA, Colabufo NA and Cohen BM et al.. (2013) Selective к opioid antagonists nor-BNI, GNTI and JDTic have low affinities for non-opioid receptors and transporters. PLoS ONE 8: e70701 [PMID:23976952]

305. Murphy NP, Ly HT and Maidment NT. (1996) Intracerebroventricular orphanin FQ/nociceptin suppresses dopamine release in the nucleus accumbens of anaesthetized rats. Neuroscience 75: 1-4 [PMID:8923516]

306. Murray RB, Adler MW and Korczyn AD. (1983) The pupillary effects of opioids. Life Sci 33: 495509 [PMID:6136886]

307. Murthy KS and Makhlouf GM. (1996) Opioid mu, delta, and kappa receptor-induced activation of phospholipase C-beta 3 and inhibition of adenylyl cyclase is mediated by Gi2 and G(o) in smooth muscle. Mol Pharmacol 50: 870-7 [PMID:8863832]

308. Nakazawa T, Furuya Y, Kaneko T and Yamatsu K. (1991) Spinal kappa receptor-mediated analgesia of E-2078, a systemically active dynorphin analog, in mice. J Pharmacol Exp Ther 256: 76-81 [PMID:1671100]

309. Narita M, Imai S, Narita M, Kasukawa A, Yajima Y and Suzuki T. (2004) Increased level of neuronal phosphoinositide 3-kinase gamma by the activation of mu-opioid receptor in the mouse periaqueductal gray matter: further evidence for the implication in morphine-induced antinociception. Neuroscience 124: 515-21 [PMID:14980723]

310. Narita M, Imai S, Ozaki S, Suzuki M, Narita M and Suzuki T. (2003) Reduced expression of a novel mu-opioid receptor (MOR) subtype MOR-1B in CXBK mice: implications of MOR-1B in the expression of MOR-mediated responses. Eur J Neurosci 18: 3193-8 [PMID:14686893]

311. Neal CR, Mansour A, Reinscheid R, Nothacker HP, Civelli O, Akil H and Watson SJ. (1999) Opioid receptor-like (ORL1) receptor distribution in the rat central nervous system: comparison of ORL1 receptor mRNA expression with ${ }^{125} \mathrm{I}-\left[{ }^{14} \mathrm{Tyr}\right]$-orphanin FQ binding. J Comp Neurol 412: 563-605 [PMID:10464356]

312. Neal Jr CR, Akil H and Watson Jr SJ. (2001) Expression of orphanin FQ and the opioid receptorlike (ORL1) receptor in the developing human and rat brain. J Chem Neuroanat 22: 219-49 [PMID:11719021]

313. Neilan CL, Akil H, Woods JH and Traynor JR. (1999) Constitutive activity of the delta-opioid receptor expressed in C6 glioma cells: identification of non-peptide delta-inverse agonists. $\mathrm{Br} \mathrm{J}$ Pharmacol 128: 556-62 [PMID:10516632]

314. Neumeyer JL, Zhang A, Xiong W, Gu XH, Hilbert JE, Knapp BI, Negus SS, Mello NK and Bidlack JM. (2003) Design and synthesis of novel dimeric morphinan ligands for kappa and micro opioid receptors. J Med Chem 46: 5162-70 [PMID:14613319]

315. Neumeyer JL, Zhang B, Zhang T, Sromek AW, Knapp BI, Cohen DJ and Bidlack JM. (2012) Synthesis, binding affinity, and functional in vitro activity of 3-benzylaminomorphinan and 3benzylaminomorphine ligands at opioid receptors. J Med Chem 55: 3878-90 [PMID:22439881]

316. Nicol B, Lambert DG, Rowbotham DJ, Smart D and McKnight AT. (1996) Nociceptin induced inhibition of $\mathrm{K}+$ evoked glutamate release from rat cerebrocortical slices. Br J Pharmacol 119: 1081-3 [PMID:8937708]

317. Nishi M, Houtani T, Noda Y, Mamiya T, Sato K, Doi T, Kuno J, Takeshima H, Nukada T and Nabeshima T et al.. (1997) Unrestrained nociceptive response and disregulation of hearing ability in mice lacking the nociceptin/orphaninFQ receptor. EMBO J 16: 1858-64 [PMID:9155012]

318. Nishi M, Takeshima H, Fukuda K, Kato S and Mori K. (1993) cDNA cloning and pharmacological characterization of an opioid receptor with high affinities for kappa-subtype-selective ligands. FEBS Lett 330: 77-80 [PMID:8396539]

319. Nishi M, Takeshima H, Mori M, Nakagawara K and Takeuchi T. (1994) Structure and chromosomal mapping of genes for the mouse kappa-opioid receptor and an opioid receptor homologue (MOR-C). Biochem Biophys Res Commun 205: 1353-7 [PMID:7802669]

320. Nock B, Rajpara A, O'Connor LH and Cicero TJ. (1988) Autoradiography of [3H]U-69593 binding sites in rat brain: evidence for kappa opioid receptor subtypes. Eur J Pharmacol 154: 27-34 [PMID:2846324]

321. North RA, Williams JT, Surprenant A and Christie MJ. (1987) Mu and delta receptors belong to a family of receptors that are coupled to potassium channels. Proc Natl Acad Sci USA 84: 5487-91 [PMID:2440052] 
322. Oertel BG, Kettner M, Scholich K, Renné C, Roskam B, Geisslinger G, Schmidt PH and Lötsch J. (2009) A common human micro-opioid receptor genetic variant diminishes the receptor signaling efficacy in brain regions processing the sensory information of pain. J Biol Chem $\mathbf{2 8 4}$ : 6530-5 [PMID:19116204]

323. Ohnishi A, Mihara M, Yasuda S, Tomono Y, Hasegawa J and Tanaka T. (1994) Aquaretic effect of the stable dynorphin-A analog E2078 in the human. J Pharmacol Exp Ther 270: 342-7 [PMID:7913498]

324. Okada K, Sujaku T, Chuman Y, Nakashima R, Nose T, Costa T, Yamada Y, Yokoyama M, Nagahisa A and Shimohigashi Y. (2000) Highly potent nociceptin analog containing the Arg-Lys triple repeat. Biochem Biophys Res Commun 278: 493-498 [PMID:11097863]

325. Okawa H, Nicol B, Bigoni R, Hirst RA, Calo G, Guerrini R, Rowbotham DJ, Smart D, McKnight AT and Lambert DG. (1999) Comparison of the effects of [Phe1psi(CH2-NH)Gly2]nociceptin(113)NH2 in rat brain, rat vas deferens and $\mathrm{CHO}$ cells expressing recombinant human nociceptin receptors. Br J Pharmacol 127: 123-30 [PMID:10369464]

326. Okuda-Ashitaka E, Minami T, Tachibana S, Yoshihara Y, Nishiuchi Y, Kimura T and Ito S. (1998) Nocistatin, a peptide that blocks nociceptin action in pain transmission. Nature 392: 286-9 [PMID:9521323]

327. Ozaki S, Kawamoto H, Itoh Y, Miyaji M, Azuma T, Ichikawa D, Nambu H, Iguchi T, Iwasawa Y and Ohta H. (2000) In vitro and in vivo pharmacological characterization of J-113397, a potent and selective non-peptidyl ORL1 receptor antagonist. Eur J Pharmacol 402: 45-53 [PMID:10940356]

328. Pak Y, Kouvelas A, Scheideler MA, Rasmussen J, O'Dowd BF and George SR. (1996) Agonistinduced functional desensitization of the mu-opioid receptor is mediated by loss of membrane receptors rather than uncoupling from G protein. Mol Pharmacol 50: 1214-22 [PMID:8913353]

329. Pan YX, Cheng J, Xu J, Rossi G, Jacobson E, Ryan-Moro J, Brooks AI, Dean GE, Standifer KM and Pasternak GW. (1995) Cloning and functional characterization through antisense mapping of a kappa 3-related opioid receptor. Mol Pharmacol 47: 1180-8 [PMID:7603458]

330. Pan YX, Xu J, Mahurter L, Bolan E, Xu M and Pasternak GW. (2001) Generation of the mu opioid receptor (MOR-1) protein by three new splice variants of the Oprm gene. Proc Natl Acad Sci USA 98: 14084-9 [PMID:11717463]

331. Pan YZ, Li DP, Chen SR and Pan HL. (2002) Activation of delta-opioid receptors excites spinally projecting locus coeruleus neurons through inhibition of GABAergic inputs. J Neurophysiol 88: 2675-83 [PMID:12424303]

332. Pande AC, Pyke RE, Greiner M, Wideman GL, Benjamin R and Pierce MW. (1996) Analgesic efficacy of enadoline versus placebo or morphine in postsurgical pain. Clin Neuropharmacol 19: 451-6 [PMID:8889289]

333. Pasternak GW and Pan YX. (2013) Mu opioids and their receptors: evolution of a concept. Pharmacol Rev 65: 1257-317 [PMID:24076545]

334. Patkar KA, Yan X, Murray TF and Aldrich JV. (2005) [Nalpha-benzylTyr1,cyclo(D-Asp5,Dap8)]dynorphin A-(1-11)NH2 cyclized in the "address" domain is a novel kappa-opioid receptor antagonist. J Med Chem 48: 4500-3 [PMID:15999987]

335. Payza K. (2003) Binding and activity of opioid ligands at the cloned human delta, mu and kappa receptors. In The Delta Receptor Edited by Chang KJ: CRC Press: 261-275 [ISBN: 0824740319]

336. Peckys D and Landwehrmeyer GB. (1999) Expression of mu, kappa, and delta opioid receptor messenger RNA in the human CNS: a 33P in situ hybridization study. Neuroscience 88: 1093135 [PMID:10336124]

337. Pelton JT, Kazmierski W, Gulya K, Yamamura HI and Hruby VJ. (1986) Design and synthesis of conformationally constrained somatostatin analogues with high potency and specificity for $\mathrm{mu}$ opioid receptors. J Med Chem 29: 2370-5 [PMID:2878079]

338. Pert CB and Snyder SH. (1973) Opiate receptor: demonstration in nervous tissue. Science 179: 1011-1014 [PMID:4687585]

339. Pfeiffer A, Braun S, Mann K, Meyer HD and Brantl V. (1986) Anterior pituitary hormone responses to a kappa-opioid agonist in man. J Clin Endocrinol Metab 62: 181-185 [PMID:3079599]

340. Pfeiffer A, Knepel W, Braun S, Meyer HD, Lohmann H and Brantl V. (1986) Effects of a kappaopioid agonist on adrenocorticotropic and diuretic function in man. Horm Metab Res 18: 842-8 [PMID:3028922]

341. Pfeiffer M, Kirscht S, Stumm R, Koch T, Wu D, Laugsch M, Schröder H, Höllt V and Schulz S. (2003) Heterodimerization of substance $\mathrm{P}$ and mu-opioid receptors regulates receptor trafficking and resensitization. J Biol Chem 278: 51630-7 [PMID:14532289]

342. Phansuwan-Pujito P, Saleema L, Mukda S, Tongjaroenbuangam W, Jutapakdeegul N, Casalotti SO, Forge A, Dodson H and Govitrapong P. (2003) The opioid receptors in inner ear of different stages of postnatal rats. Hear Res 184: 1-10 [PMID:14553898]

343. Philippe D, Dubuquoy L, Groux H, Brun V, Chuoï-Mariot MT, Gaveriaux-Ruff C, Colombel JF, Kieffer BL and Desreumaux P. (2003) Anti-inflammatory properties of the mu opioid receptor 
support its use in the treatment of colon inflammation. J Clin Invest 111: 1329-38

[PMID:12727924]

344. Piros ET, Prather PL, Law PY, Evans CJ and Hales TG. (1996) Voltage-dependent inhibition of Ca2 + channels in GH3 cells by cloned mu- and delta-opioid receptors. Mol Pharmacol 50: 94756 [PMID:8863841]

345. Piros ET, Prather PL, Loh HH, Law PY, Evans CJ and Hales TG. (1995) Ca2+ channel and adenylyl cyclase modulation by cloned mu-opioid receptors in GH3 cells. Mol Pharmacol 47: 1041-9 [PMID:7746271]

346. Poeaknapo C, Schmidt J, Brandsch M, Dräger B and Zenk MH. (2004) Endogenous formation of morphine in human cells. Proc Natl Acad Sci USA 101: 14091-6 [PMID:15383669]

347. Pol O, Palacio JR and Puig MM. (2003) The expression of delta- and kappa-opioid receptor is enhanced during intestinal inflammation in mice. J Pharmacol Exp Ther 306: 455-62 [PMID:12724348]

348. Poole DP, Pelayo JC, Scherrer G, Evans CJ, Kieffer BL and Bunnett NW. (2011) Localization and regulation of fluorescently labeled delta opioid receptor, expressed in enteric neurons of mice. Gastroenterology 141: 982-991.e1-8 [PMID:21699782]

349. Portoghese PS. (1965) A new concept on the mode of interaction of narcotic analgesics with receptors. J Med Chem 8: 609-16 [PMID:5867942]

350. Portoghese PS, Larson DL, Ronsisvalle G, Schiller PW, Nguyen TM, Lemieux C and Takemori AE. (1987) Hybrid bivalent ligands with opiate and enkephalin pharmacophores. J Med Chem 30: 1991-4 [PMID:2444704]

351. Portoghese PS, Sultana M and Takemori AE. (1988) Naltrindole, a highly selective and potent non-peptide delta opioid receptor antagonist. Eur J Pharmacol 146: 185-6 [PMID:2832195]

352. Poulain R, Horvath D, Bonnet B, Eckhoff C, Chapelain B, Bodinier MC and Déprez B. (2001) From hit to lead. Combining two complementary methods for focused library design. Application to mu opiate ligands. J Med Chem 44: 3378-90 [PMID:11585443]

353. Prchalová E, Hin N, Thomas AG, Veeravalli V, Ng J, Alt J, Rais R, Rojas C, Li Z and Hihara H et al.. (2019) Discovery of Benzamidine- and 1-Aminoisoquinoline-Based Human MAS-Related GProtein-Coupled Receptor X1 (MRGPRX1) Agonists. J Med Chem 62: 8631-8641 [PMID:31498617]

354. Quock RM, Hosohata Y, Knapp RJ, Burkey TH, Hosohata K, Zhang X, Rice KC, Nagase H, Hruby VJ and Porreca F et al.. (1997) Relative efficacies of delta-opioid receptor agonists at the cloned human delta-opioid receptor. Eur J Pharmacol 326: 101-4 [PMID:9178661]

355. Ravert HT, Scheffel U, Mathews WB, Musachio JL and Dannals RF. (2002) [(11)C]-GR89696, a potent kappa opiate receptor radioligand; in vivo binding of the R and S enantiomers. Nucl Med Biol 29: 47-53 [PMID:11786275]

356. Raynor K, Kong H, Chen Y, Yasuda K, Yu L, Bell GI and Reisine T. (1994) Pharmacological characterization of the cloned kappa-, delta-, and mu-opioid receptors. Mol Pharmacol 45: 330-4 [PMID:8114680]

357. Reinscheid RK, Nothacker HP, Bourson A, Ardati A, Henningsen RA, Bunzow JR, Grandy DK, Langen H, Monsma Jr FJ and Civelli O. (1995) Orphanin FQ: a neuropeptide that activates an opioidlike G protein-coupled receptor. Science 270: 792-4 [PMID:7481766]

358. Remmers AE, Clark MJ, Mansour A, Akil H, Woods JH and Medzihradsky F. (1999) Opioid efficacy in a C6 glioma cell line stably expressing the human kappa opioid receptor. J Pharmacol Exp Ther 288: 827-33 [PMID:9918595]

359. Rhim H and Miller RJ. (1994) Opioid receptors modulate diverse types of calcium channels in the nucleus tractus solitarius of the rat. J Neurosci 14: 7608-15 [PMID:7996199]

360. Rimoy GH, Bhaskar NK, Wright DM and Rubin PC. (1991) Mechanism of diuretic action of spiradoline (U-62066E)--a kappa opioid receptor agonist in the human. BrJ Clin Pharmacol 32: 611-5 [PMID:1659438]

361. Rimoy GH, Wright DM, Bhaskar NK and Rubin PC. (1994) The cardiovascular and central nervous system effects in the human of U-62066E. A selective opioid receptor agonist. Eur J Clin Pharmacol 46: 203-7 [PMID:8070500]

362. Rios CD, Jordan BA, Gomes I and Devi LA. (2001) G-protein-coupled receptor dimerization: modulation of receptor function. Pharmacol Ther 92: 71-87 [PMID:11916530]

363. Rizzi A, Malfacini D, Cerlesi MC, Ruzza C, Marzola E, Bird MF, Rowbotham DJ, Salvadori S, Guerrini R and Lambert DG et al.. (2014) In vitro and in vivo pharmacological characterization of nociceptin/orphanin FQ tetrabranched derivatives. Br J Pharmacol 171: 4138-53 [PMID:24903280]

364. Rizzi A, Spagnolo B, Wainford RD, Fischetti C, Guerrini R, Marzola G, Baldisserotto A, Salvadori S, Regoli D and Kapusta DR et al.. (2007) In vitro and in vivo studies on UFP-112, a novel potent and long lasting agonist selective for the nociceptin/orphanin FQ receptor. Peptides 28: 1240-51 [PMID:17532097]

365. Rorick-Kehn LM, Witkin JM, Statnick MA, Eberle EL, McKinzie JH, Kahl SD, Forster BM, Wong CJ, Li X and Crile RS et al.. (2014) LY2456302 is a novel, potent, orally-bioavailable small 
molecule kappa-selective antagonist with activity in animal models predictive of efficacy in mood and addictive disorders. Neuropharmacology 77: 131-44 [PMID:24071566]

366. Roth BL, Baner K, Westkaemper R, Siebert D, Rice KC, Steinberg S, Ernsberger P and Rothman RB. (2002) Salvinorin A: a potent naturally occurring nonnitrogenous kappa opioid selective agonist. Proc Natl Acad Sci USA 99: 11934-9 [PMID:12192085]

367. Rothman RB, France CP, Bykov V, De Costa BR, Jacobson AE, Woods JH and Rice KC. (1989) Pharmacological activities of optically pure enantiomers of the kappa opioid agonist, U50,488, and its cis diastereomer: evidence for three kappa receptor subtypes. Eur J Pharmacol 167: 34553 [PMID:2553442]

368. Roy S, Balasubramanian S, Sumandeep S, Charboneau R, Wang J, Melnyk D, Beilman GJ, Vatassery R and Barke RA. (2001) Morphine directs T cells toward T(H2) differentiation. Surgery 130: 304-9 [PMID:11490364]

369. Roy S, Barke RA and Loh HH. (1998) MU-opioid receptor-knockout mice: role of mu-opioid receptor in morphine mediated immune functions. Brain Res Mol Brain Res 61: 190-4 [PMID:9795212]

370. Salemi S, Aeschlimann A, Reisch N, Jüngel A, Gay RE, Heppner FL, Michel BA, Gay S and Sprott H. (2005) Detection of kappa and delta opioid receptors in skin--outside the nervous system. Biochem Biophys Res Commun 338: 1012-7 [PMID:16263089]

371. Satoh M and Minami M. (1995) Molecular pharmacology of the opioid receptors. Pharmacol Ther 68: 343-64 [PMID:8788562]

372. Scherrer G, Befort K, Contet C, Becker J, Matifas A and Kieffer BL. (2004) The delta agonists DPDPE and deltorphin II recruit predominantly mu receptors to produce thermal analgesia: a parallel study of mu, delta and combinatorial opioid receptor knockout mice. Eur J Neurosci 19: 2239-48 [PMID:15090050]

373. Scherrer G, Tryoen-Tóth P, Filliol D, Matifas A, Laustriat D, Cao YQ, Basbaum AI, Dierich A, Vonesh JL and Gavériaux-Ruff C et al.. (2006) Knockin mice expressing fluorescent delta-opioid receptors uncover G protein-coupled receptor dynamics in vivo. Proc Natl Acad Sci USA 103: 9691-6 [PMID:16766653]

374. Schiller PW, Weltrowska G, Nguyen TM, Wilkes BC, Chung NN and Lemieux C. (1993) TIPP[psi]: a highly potent and stable pseudopeptide delta opioid receptor antagonist with extraordinary delta selectivity. J Med Chem 36: 3182-7 [PMID:8230106]

375. Schlicker E, Werthwein S, Kathmann M and Bauer U. (1998) Nociceptin inhibits noradrenaline release in the mouse brain cortex via presynaptic ORL1 receptors. Naunyn Schmiedebergs Arch Pharmacol 358: 418-22 [PMID:9826063]

376. Schmauss C and Yaksh TL. (1984) In vivo studies on spinal opiate receptor systems mediating antinociception. II. Pharmacological profiles suggesting a differential association of mu, delta and kappa receptors with visceral chemical and cutaneous thermal stimuli in the rat. $J$ Pharmacol Exp Ther 228: 1-12 [PMID:6319664]

377. Schnell SA and Wessendorf MW. (2004) Expression of MOR1C-like mu-opioid receptor mRNA in rats. J Comp Neurol 473: 213-32 [PMID:15101090]

378. Schoffelmeer AN, Rice KC, Jacobson AE, Van Gelderen JG, Hogenboom F, Heijna MH and Mulder AH. (1988) Mu-, delta- and kappa-opioid receptor-mediated inhibition of neurotransmitter release and adenylate cyclase activity in rat brain slices: studies with fentanyl isothiocyanate. Eur J Pharmacol 154: 169-178 [PMID:2906610]

379. Schteingart CD, Menzaghi F, Jiang G, Alexander RV, Sueiras-Diaz J, Spencer RH, Chalmers DT and Luo Z. (2008) Synthetic peptide amides. Patent number: US7402564 B1.

380. Schulz R, Eisinger DA and Wehmeyer A. (2004) Opioid control of MAP kinase cascade. Eur J Pharmacol 500: 487-97 [PMID:15464054]

381. Schulz S, Schreff M, Koch T, Zimprich A, Gramsch C, Elde R and Höllt V. (1998) Immunolocalization of two mu-opioid receptor isoforms (MOR1 and MOR1B) in the rat central nervous system. Neuroscience 82: 613-22 [PMID:9466465]

382. Sengupta JN, Su X and Gebhart GF. (1996) Kappa, but not mu or delta, opioids attenuate responses to distention of afferent fibers innervating the rat colon. Gastroenterology 111: 96880 [PMID:8831591]

383. Seth P, Fei YJ, Li HW, Huang W, Leibach FH and Ganapathy V. (1998) Cloning and functional characterization of a sigma receptor from rat brain. J Neurochem 70: 922-31 [PMID:9489711]

384. Sharif NA and Hughes J. (1989) Discrete mapping of brain $\mathrm{Mu}$ and delta opioid receptors using selective peptides: quantitative autoradiography, species differences and comparison with kappa receptors. Peptides 10: 499-522 [PMID:2550910]

385. Sharma SK, Klee WA and Nirenberg M. (1977) Opiate-dependent modulation of adenylate cyclase. Proc Natl Acad Sci USA 74: 3365-9 [PMID:269396]

386. Sharp BM, Roy S and Bidlack JM. (1998) Evidence for opioid receptors on cells involved in host defense and the immune system. J Neuroimmunol 83: 45-56 [PMID:9610672]

387. Shinkai H, Ito T, Iida T, Kitao Y, Yamada H and Uchida I. (2000) 4-Aminoquinolines: novel nociceptin antagonists with analgesic activity. J Med Chem 43: 4667-77 [PMID:11101358] 
388. Shippenberg TS and Herz A. (1987) Place preference conditioning reveals the involvement of D1-dopamine receptors in the motivational properties of mu- and kappa-opioid agonists. Brain Res 436: 169-72 [PMID:2961413]

389. Sim LJ, Selley DE and Childers SR. (1995) In vitro autoradiography of receptor-activated G proteins in rat brain by agonist-stimulated guanylyl 5'-[gamma-[35S]thio]-triphosphate binding. Proc Natl Acad Sci USA 92: 7242-6 [PMID:7638174]

390. Sim LJ, Xiao R and Childers SR. (1996) Identification of opioid receptor-like (ORL1) peptidestimulated [35S]GTP gamma S binding in rat brain. Neuroreport 7: 729-33 [PMID:8733732]

391. Simon EJ, Hiller JM and Edelman I. (1973) Stereospecific binding of the potent narcotic analgesic $\left[{ }^{3} \mathrm{H}\right]$ etorphine to rat brain homogenate. Proc Natl Acad Sci USA 70: 1947-1949 [PMID:4516196]

392. Simonin F, Befort K, Gavériaux-Ruff C, Matthes H, Nappey V, Lannes B, Micheletti G and Kieffer B. (1994) The human delta-opioid receptor: genomic organization, cDNA cloning, functional expression, and distribution in human brain. Mol Pharmacol 46: 1015-21 [PMID:7808419]

393. Simonin F, Gavériaux-Ruff C, Befort K, Matthes H, Lannes B, Micheletti G, Mattéi MG, Charron G, Bloch B and Kieffer B. (1995) kappa-Opioid receptor in humans: cDNA and genomic cloning, chromosomal assignment, functional expression, pharmacology, and expression pattern in the central nervous system. Proc Natl Acad Sci USA 92: 7006-10 [PMID:7624359]

394. Simonin F, Slowe S, Becker JA, Matthes HW, Filliol D, Chluba J, Kitchen I and Kieffer BL. (2001) Analysis of $[3 \mathrm{H}]$ bremazocine binding in single and combinatorial opioid receptor knockout mice. Eur J Pharmacol 414: 189-95 [PMID:11239918]

395. Simonin F, Valverde O, Smadja C, Slowe S, Kitchen I, Dierich A, Le Meur M, Roques BP, Maldonado R and Kieffer BL. (1998) Disruption of the kappa-opioid receptor gene in mice enhances sensitivity to chemical visceral pain, impairs pharmacological actions of the selective kappa-agonist U-50,488H and attenuates morphine withdrawal. EMBOJ 17: 886-97 [PMID:9463367]

396. Singhal P, Kapasi A, Reddy K and Franki N. (2001) Opiates promote T cell apoptosis through JNK and caspase pathway. Adv Exp Med Biol 493: 127-135 [PMID:11727758]

397. Slizgi GR and Ludens JH. (1982) Studies on the nature and mechanism of the diuretic activity of the opioid analgesic ethylketocyclazocine. J Pharmacol Exp Ther 220: 585-91 [PMID:6121047]

398. Slowe SJ, Clarke S, Lena I, Goody RJ, Lattanzi R, Negri L, Simonin F, Matthes HW, Filliol D, Kieffer BL and Kitchen I. (2001) Autoradiographic mapping of the opioid receptor-like 1 (ORL1) receptor in the brains of mu-, delta- or kappa-opioid receptor knockout mice. Neuroscience 106: 469-480 [PMID:11591451]

399. Smith CF, Waldron C and Brook NA. (1988) Opioid receptors in the mouse ileum. Arch Int Pharmacodyn Ther 291: 122-31 [PMID:2835021]

400. Sofuoglu M, Portoghese PS and Takemori AE. (1991) Differential antagonism of delta opioid agonists by naltrindole and its benzofuran analog (NTB) in mice: evidence for delta opioid receptor subtypes. J Pharmacol Exp Ther 257: 676-80 [PMID:1851833]

401. Sora I, Funada M and Uhl GR. (1997) The mu-opioid receptor is necessary for [D-Pen2,DPen5] enkephalin-induced analgesia. Eur J Pharmacol 324: R1-2 [PMID:9145787]

402. Sora I, Takahashi N, Funada M, Ujike H, Revay RS, Donovan DM, Miner LL and Uhl GR. (1997) Opiate receptor knockout mice define mu receptor roles in endogenous nociceptive responses and morphine-induced analgesia. Proc Natl Acad Sci USA 94: 1544-9 [PMID:9037090]

403. Spagnolo B, Carrà G, Fantin M, Fischetti C, Hebbes C, McDonald J, Barnes TA, Rizzi A, Trapella $\mathrm{C}$ and Fanton G et al.. (2007) Pharmacological characterization of the nociceptin/orphanin FQ receptor antagonist SB-612111 [(-)-cis-1-methyl-7-[[4-(2,6-dichlorophenyl)piperidin-1yl]methyl]-6,7,8,9-tetrahydro-5H-benzocyclohepten-5-ol]: in vitro studies. J Pharmacol Exp Ther 321: 961-7 [PMID:17329552]

404. Spanagel R, Herz A and Shippenberg TS. (1990) The effects of opioid peptides on dopamine release in the nucleus accumbens: an in vivo microdialysis study. J Neurochem 55: 1734-40 [PMID:1976759]

405. Spetea M, Berzetei-Gurske IP, Guerrieri E and Schmidhammer H. (2012) Discovery and pharmacological evaluation of a diphenethylamine derivative (HS665), a highly potent and selective $\mathrm{k}$ opioid receptor agonist. J Med Chem 55: 10302-6 [PMID:23134120]

406. Stefano GB, Melchiorri P, Negri L, Hughes TK and Scharrer B. (1992) [D-Ala2]deltorphin I binding and pharmacological evidence for a special subtype of delta opioid receptor on human and invertebrate immune cells. Proc Natl Acad Sci USA 89: 9316-20 [PMID:1329092]

407. Stein C, Millan MJ, Shippenberg TS, Peter K and Herz A. (1989) Peripheral opioid receptors mediating antinociception in inflammation. Evidence for involvement of mu, delta and kappa receptors. J Pharmacol Exp Ther 248: 1269-75 [PMID:2539460]

408. Stevens WC, Jones RM, Subramanian G, Metzger TG, Ferguson DM and Portoghese PS. (2000) Potent and selective indolomorphinan antagonists of the kappa-opioid receptor. J Med Chem 43: 2759-69 [PMID:10893314]

409. Ständer S, Gunzer M, Metze D, Luger T and Steinhoff M. (2002) Localization of mu-opioid 
receptor 1A on sensory nerve fibers in human skin. Regul Pept 110: 75-83 [PMID:12468112]

410. Svingos AL, Moriwaki A, Wang JB, Uhl GR and Pickel VM. (1996) Ultrastructural immunocytochemical localization of mu-opioid receptors in rat nucleus accumbens: extrasynaptic plasmalemmal distribution and association with Leu5-enkephalin. J Neurosci 16: 4162-73 [PMID:8753878]

411. Svingos AL, Moriwaki A, Wang JB, Uhl GR and Pickel VM. (1997) mu-Opioid receptors are localized to extrasynaptic plasma membranes of GABAergic neurons and their targets in the rat nucleus accumbens. J Neurosci 17: 2585-94 [PMID:9065518]

412. Szekeres PG and Traynor JR. (1997) Delta opioid modulation of the binding of guanosine-5'-O-(3[35S]thio)triphosphate to NG108-15 cell membranes: characterization of agonist and inverse agonist effects. J Pharmacol Exp Ther 283: 1276-84 [PMID:9400003]

413. Tallent M, Dichter MA, Bell GI and Reisine T. (1994) The cloned kappa opioid receptor couples to an N-type calcium current in undifferentiated PC-12 cells. Neuroscience 63: 1033-40 [PMID:7700508]

414. Taub DD, Eisenstein TK, Geller EB, Adler MW and Rogers TJ. (1991) Immunomodulatory activity of mu- and kappa-selective opioid agonists. Proc Natl Acad Sci USA 88: 360-4 [PMID:1846441]

415. Tempel A and Zukin RS. (1987) Neuroanatomical patterns of the mu, delta, and kappa opioid receptors of rat brain as determined by quantitative in vitro autoradiography. Proc Natl Acad Sci USA 84: 4308-12 [PMID:3035579]

416. Terenius L. (1973) Stereospecific interaction between narcotic analgesics and a synaptic plasma membrane fraction of rat cerebral cortex. Acta Pharmacol Toxicol 32: 317-320 [PMID:4801733]

417. Thomas JB, Atkinson RN, Rothman RB, Fix SE, Mascarella SW, Vinson NA, Xu H, Dersch CM, Lu $\mathrm{Y}$ and Cantrell BE et al.. (2001) Identification of the first trans-(3R,4R)- dimethyl-4-(3hydroxyphenyl)piperidine derivative to possess highly potent and selective opioid kappa receptor antagonist activity. J Med Chem 44: 2687-90 [PMID:11495579]

418. Thompson AA, Liu W, Chun E, Katritch V, Wu H, Vardy E, Huang XP, Trapella C, Guerrini R and Calo G et al.. (2012) Structure of the nociceptin/orphanin FQ receptor in complex with a peptide mimetic. Nature 485: 395-9 [PMID:22596163]

419. Thompson RC, Mansour A, Akil H and Watson SJ. (1993) Cloning and pharmacological characterization of a rat mu opioid receptor. Neuron 11: 903-13 [PMID:8240812]

420. Tian M, Broxmeyer HE, Fan Y, Lai Z, Zhang S, Aronica S, Cooper S, Bigsby RM, Steinmetz R, Engle SJ, Mestek A, Pollock JD, Lehman MN, Jansen HT, Ying M, Stambrook PJ, Tischfield JA and Yu L. (1997) Altered hematopoiesis, behavior, and sexual function in mu opioid receptordeficient mice. J Exp Med 185: 1517-1522 [PMID:9126934]

421. Tien LT, Fan LW, Sogawa C, Ma T, Loh HH and Ho IK. (2004) Changes in acetylcholinesterase activity and muscarinic receptor bindings in mu-opioid receptor knockout mice. Brain Res Mol Brain Res 126: 38-44 [PMID:15207914]

422. Tien LT, Park Y, Fan LW, Ma T, Loh HH and Ho IK. (2003) Increased dopamine D2 receptor binding and enhanced apomorphine-induced locomotor activity in mu-opioid receptor knockout mice. Brain Res Bull 61: 109-15 [PMID:12788214]

423. Togashi Y, Umeuchi H, Okano K, Ando N, Yoshizawa Y, Honda T, Kawamura K, Endoh T, Utsumi $\mathrm{J}$ and Kamei J et al.. (2002) Antipruritic activity of the kappa-opioid receptor agonist, TRK-820. Eur J Pharmacol 435: 259-64 [PMID:11821035]

424. Toledo MA, Pedregal C, Lafuente C, Diaz N, Martinez-Grau MA, Jiménez A, Benito A, Torrado A, Mateos C and Joshi EM et al.. (2014) Discovery of a novel series of orally active nociceptin/orphanin FQ (NOP) receptor antagonists based on a dihydrospiro(piperidine-4,7'thieno[2,3-c]pyran) scaffold. J Med Chem 57: 3418-29 [PMID:24678969]

425. Toll L, Berzetei-Gurske IP, Polgar WE, Brandt SR, Adapa ID, Rodriguez L, Schwartz RW, Haggart D, O'Brien A and White A et al.. (1998) Standard binding and functional assays related to medications development division testing for potential cocaine and opiate narcotic treatment medications. NIDA Res Monogr 178: 440-66 [PMID:9686407]

426. Toll L, Khroyan TV, Polgar WE, Jiang F, Olsen C and Zaveri NT. (2009) Comparison of the antinociceptive and antirewarding profiles of novel bifunctional nociceptin receptor/mu-opioid receptor ligands: implications for therapeutic applications. J Pharmacol Exp Ther 331: 954-64 [PMID:19773529]

427. Trafton JA, Abbadie C, Marek K and Basbaum AI. (2000) Postsynaptic signaling via the [mu]opioid receptor: responses of dorsal horn neurons to exogenous opioids and noxious stimulation. J Neurosci 20: 8578-84 [PMID:11102461]

428. Trapella C, Guerrini R, Piccagli L, Calo' G, Carra' G, Spagnolo B, Rubini S, Fanton G, Hebbes C and McDonald J et al.. (2006) Identification of an achiral analogue of J-113397 as potent nociceptin/orphanin FQ receptor antagonist. Bioorg Med Chem 14: 692-704 [PMID:16202610]

429. Tyers MB. (1980) A classification of opiate receptors that mediate antinociception in animals. $\mathrm{Br}$ J Pharmacol 69: 503-12 [PMID:6249436]

430. Tzschentke TM, Christoph T, Kögel B, Schiene K, Hennies HH, Englberger W, Haurand M, Jahnel U, Cremers TI and Friderichs E et al.. (2007) (-)-(1R,2R)-3-(3-dimethylamino-1-ethyl-2- 
methyl-propyl)-phenol hydrochloride (tapentadol $\mathrm{HCl}$ ): a novel mu-opioid receptor agonist/norepinephrine reuptake inhibitor with broad-spectrum analgesic properties. $J$ Pharmacol Exp Ther 323: 265-76 [PMID:17656655]

431. Ueda H, Inoue M, Takeshima H and Iwasawa Y. (2000) Enhanced spinal nociceptin receptor expression develops morphine tolerance and dependence. J Neurosci 20: 7640-7 [PMID:11027224]

432. Ueda H, Miyamae T, Fukushima N, Takeshima H, Fukuda K, Sasaki Y and Misu Y. (1995) Opioid mu- and kappa-receptor mediate phospholipase C activation through Gi1 in Xenopus oocytes. Brain Res Mol Brain Res 32: 166-70 [PMID:7494457]

433. Unterwald EM, Knapp C and Zukin RS. (1991) Neuroanatomical localization of kappa 1 and kappa 2 opioid receptors in rat and guinea pig brain. Brain Res 562: 57-65 [PMID:1666016]

434. Van Bockstaele EJ, Colago EE, Cheng P, Moriwaki A, Uhl GR and Pickel VM. (1996) Ultrastructural evidence for prominent distribution of the mu-opioid receptor at extrasynaptic sites on noradrenergic dendrites in the rat nucleus locus coeruleus. J Neurosci 16: 5037-5048 [PMID:8756434]

435. Van Bockstaele EJ, Colago EE, Moriwaki A and Uhl GR. (1996) Mu-opioid receptor is located on the plasma membrane of dendrites that receive asymmetric synapses from axon terminals containing leucine-enkephalin in the rat nucleus locus coeruleus. J Comp Neurol 376: 65-74 [PMID:8946284]

436. Varty GB, Lu SX, Morgan CA, Cohen-Williams ME, Hodgson RA, Smith-Torhan A, Zhang H, Fawzi AB, Graziano MP and Ho GD et al.. (2008) The anxiolytic-like effects of the novel, orally active nociceptin opioid receptor agonist 8-[bis(2-methylphenyl)methyl]-3-phenyl-8azabicyclo[3.2.1] octan-3-ol (SCH 221510). J Pharmacol Exp Ther 326: 672-82 [PMID:18492950]

437. Vergura R, Balboni G, Spagnolo B, Gavioli E, Lambert DG, McDonald J, Trapella C, Lazarus LH, Regoli D and Guerrini R et al.. (2008) Anxiolytic- and antidepressant-like activities of H-Dmt-Tic$\mathrm{NH}-\mathrm{CH}(\mathrm{CH} 2-\mathrm{COOH})-\mathrm{Bid}$ (UFP-512), a novel selective delta opioid receptor agonist. Peptides 29: 93-103 [PMID:18069089]

438. Volpe DA, McMahon Tobin GA, Mellon RD, Katki AG, Parker RJ, Colatsky T, Kropp TJ and Verbois SL. (2011) Uniform assessment and ranking of opioid $\mu$ receptor binding constants for selected opioid drugs. Regul Toxicol Pharmacol 59: 385-90 [PMID:21215785]

439. Vonvoigtlander PF, Lahti RA and Ludens JH. (1983) U-50,488: a selective and structurally novel non-Mu (kappa) opioid agonist. J Pharmacol Exp Ther 224: 7-12 [PMID:6129321]

440. Wang D, Tolbert LM, Carlson KW and Sadée W. (2000) Nuclear Ca2+/calmodulin translocation activated by mu-opioid (OP3) receptor. J Neurochem 74: 1418-25 [PMID:10737597]

441. Wang H, Moriwaki A, Wang JB, Uhl GR and Pickel VM. (1997) Ultrastructural immunocytochemical localization of mu-opioid receptors in dendritic targets of dopaminergic terminals in the rat caudate-putamen nucleus. Neuroscience 81: 757-71 [PMID:9316027]

442. Wang HL, Hsu CY, Huang PC, Kuo YL, Li AH, Yeh TH, Tso AS and Chen YL. (2005) Heterodimerization of opioid receptor-like 1 and mu-opioid receptors impairs the potency of micro receptor agonist. J Neurochem 92: 1285-94 [PMID:15748148]

443. Wang J, Barke RA, Charboneau R, Loh HH and Roy S. (2003) Morphine negatively regulates interferon-gamma promoter activity in activated murine T cells through two distinct cyclic AMPdependent pathways. J Biol Chem 278: 37622-31 [PMID:12842891]

444. Wang JB, Imai Y, Eppler CM, Gregor P, Spivak CE and Uhl GR. (1993) mu opiate receptor: cDNA cloning and expression. Proc Natl Acad Sci USA 90: 10230-4 [PMID:8234282]

445. Wang JB, Johnson PS, Imai Y, Persico AM, Ozenberger BA, Eppler CM and Uhl GR. (1994) cDNA cloning of an orphan opiate receptor gene family member and its splice variant. FEBS Lett 348: 75-9 [PMID:8026588]

446. Wang JB, Johnson PS, Persico AM, Hawkins AL, Griffin CA and Uhl GR. (1994) Human mu opiate receptor. cDNA and genomic clones, pharmacologic characterization and chromosomal assignment. FEBS Lett 338: 217-22 [PMID:7905839]

447. Wang Y, Tang K, Inan S, Siebert D, Holzgrabe U, Lee DY, Huang P, Li JG, Cowan A and Liu-Chen LY. (2005) Comparison of pharmacological activities of three distinct kappa ligands (Salvinorin A, TRK-820 and 3FLB) on kappa opioid receptors in vitro and their antipruritic and antinociceptive activities in vivo. J Pharmacol Exp Ther 312: 220-30 [PMID:15383632]

448. Wentland MP, Lou R, Lu Q, Bu Y, Denhardt C, Jin J, Ganorkar R, VanAlstine MA, Guo C and Cohen DJ et al.. (2009) Syntheses of novel high affinity ligands for opioid receptors. Bioorg Med Chem Lett 19: 2289-94 [PMID:19282177]

449. Wentland MP, Lou R, Lu Q, Bu Y, VanAlstine MA, Cohen DJ and Bidlack JM. (2009) Syntheses and opioid receptor binding properties of carboxamido-substituted opioids. Bioorg Med Chem Lett 19: 203-8 [PMID:19027293]

450. Wentland MP, Lu Q, Lou R, Bu Y, Knapp BI and Bidlack JM. (2005) Synthesis and opioid receptor binding properties of a highly potent 4-hydroxy analogue of naltrexone. Bioorg Med Chem Lett 15: 2107-10 [PMID:15808478]

451. Wichmann J, Adam G, Röver S, Cesura AM, Dautzenberg FM and Jenck F. (1999) 8- 
acenaphthen-1-yl-1-phenyl-1,3,8-triaza-spiro[4.5]decan-4-one derivatives as orphanin FQ receptor agonists. Bioorg Med Chem Lett 9: 2343-8 [PMID:10476866]

452. Wichmann J, Adam G, Röver S, Hennig M, Scalone M, Cesura AM, Dautzenberg FM and Jenck F. (2000) Synthesis of (1S,3aS)-8-(2,3,3a,4,5, 6-hexahydro-1H-phenalen-1-yl)-1-phenyl-1,3,8-triazaspiro[4. 5]decan-4-one, a potent and selective orphanin FQ (OFQ) receptor agonist with anxiolytic-like properties. Eur J Med Chem 35: 839-51 [PMID:11006485]

453. Wu H, Wacker D, Mileni M, Katritch V, Han GW, Vardy E, Liu W, Thompson AA, Huang XP and Carroll FI et al.. (2012) Structure of the human K-opioid receptor in complex with JDTic. Nature 485: 327-32 [PMID:22437504]

454. Wüster M, Schulz R and Herz A. (1979) Specificity of opioids towards the mu-, delta- and epsilon-opiate receptors. Neurosci Lett 15: 193-8 [PMID:231238]

455. Xie CW, Morrisett RA and Lewis DV. (1992) Mu opioid receptor-mediated modulation of synaptic currents in dentate granule cells of rat hippocampus. J Neurophysiol 68: 1113-20 [PMID:1359026]

456. Xie Z, Bhushan RG, Daniels DJ and Portoghese PS. (2005) Interaction of bivalent ligand KDN21 with heterodimeric delta-kappa opioid receptors in human embryonic kidney 293 cells. Mol Pharmacol 68: 1079-1086 [PMID:16006595]

457. Xu XJ, Hao JX and Wiesenfeld-Hallin Z. (1996) Nociceptin or antinociceptin: potent spinal antinociceptive effect of orphanin FQ/nociceptin in the rat. Neuroreport 7: 2092-4 [PMID:8930965]

458. Yaksh TL and Noueihed R. (1985) The physiology and pharmacology of spinal opiates. Annu Rev Pharmacol Toxicol 25: 433-62 [PMID:2988422]

459. Yamamura MS, Horvath R, Toth G, Otvos F, Malatynska E, Knapp RJ, Porreca F, Hruby VJ and Yamamura HI. (1992) Characterization of [3H]naltrindole binding to delta opioid receptors in rat brain. Life Sci 50: PL119-24 [PMID:1313133]

460. Yasuda K, Raynor K, Kong H, Breder CD, Takeda J, Reisine T and Bell GI. (1993) Cloning and functional comparison of kappa and delta opioid receptors from mouse brain. Proc Natl Acad Sci USA 90: 6736-40 [PMID:8393575]

461. Yeadon $\mathrm{M}$ and Kitchen I. (1988) Comparative binding of mu and delta selective ligands in whole brain and pons/medulla homogenates from rat: affinity profiles of fentanyl derivatives. Neuropharmacology 27: 345-8 [PMID:2843777]

462. Yoo JH, Yang EM, Lee SY, Loh HH, Ho IK and Jang CG. (2003) Differential effects of morphine and cocaine on locomotor activity and sensitization in mu-opioid receptor knockout mice. Neurosci Lett 344: 37-40 [PMID:12781916]

463. Yoshimura M, Ikeda H and Tabakoff B. (1996) mu-Opioid receptors inhibit dopamine-stimulated activity of type $\mathrm{V}$ adenylyl cyclase but enhance dopamine-stimulated activity of type VII adenylyl cyclase. Mol Pharmacol 50: 43-51 [PMID:8700117]

464. Yoshino H, Nakazawa T, Arakawa Y, Kaneko T, Tsuchiya Y, Matsunaga M, Araki S, Ikeda M, Yamatsu K and Tachibana S. (1990) Synthesis and structure-activity relationships of dynorphin A-(1-8) amide analogues. J Med Chem 33: 206-12 [PMID:1967312]

465. Yu VC, Eiger S, Duan DS, Lameh J and Sadée W. (1990) Regulation of cyclic AMP by the muopioid receptor in human neuroblastoma SH-SY5Y cells. J Neurochem 55: 1390-6 [PMID:1697894]

466. Yuen JW, So IY, Kam AY and Wong YH. (2004) Regulation of STAT3 by mu-opioid receptors in human neuroblastoma SH-SY5Y cells. Neuroreport 15: 1431-5 [PMID:15194868]

467. Yuferov V, Fussell D, LaForge KS, Nielsen DA, Gordon D, Ho A, Leal SM, Ott J and Kreek MJ. (2004) Redefinition of the human kappa opioid receptor gene (OPRK1) structure and association of haplotypes with opiate addiction. Pharmacogenetics 14: 793-804 [PMID:15608558]

468. Zachariou V, Georgescu D, Sanchez N, Rahman Z, DiLeone R, Berton O, Neve RL, Sim-Selley LJ, Selley DE and Gold SJ et al.. (2003) Essential role for RGS9 in opiate action. Proc Natl Acad Sci USA 100: 13656-61 [PMID:14595021]

469. Zadina JE, Hackler L, Ge LJ and Kastin AJ. (1997) A potent and selective endogenous agonist for the mu-opiate receptor. Nature 386: 499-502 [PMID:9087409]

470. Zagon IS, Gibo DM and McLaughlin PJ. (1991) Zeta (zeta), a growth-related opioid receptor in developing rat cerebellum: identification and characterization. Brain Res 551: 28-35 [PMID:1655161]

471. Zagon IS, Verderame MF, Allen SS and McLaughlin PJ. (1999) Cloning, sequencing, expression and function of a cDNA encoding a receptor for the opioid growth factor, [Met(5)]enkephalin. Brain Res 849: 147-54 [PMID:10592296]

472. Zagon IS, Verderame MF and McLaughlin PJ. (2002) The biology of the opioid growth factor receptor (OGFr). Brain Res Brain Res Rev 38: 351-76 [PMID:11890982]

473. Zaki PA, Bilsky EJ, Vanderah TW, Lai J, Evans CJ and Porreca F. (1996) Opioid receptor types and subtypes: the delta receptor as a model. Annu Rev Pharmacol Toxicol 36: 379-401 [PMID:8725395]

474. Zaratin PF, Petrone G, Sbacchi M, Garnier M, Fossati C, Petrillo P, Ronzoni S, Giardina GA and 
Scheideler MA. (2004) Modification of nociception and morphine tolerance by the selective opiate receptor-like orphan receptor antagonist (-)-cis-1-methyl-7-[[4-(2,6-

dichlorophenyl)piperidin-1-yl]methyl]-6,7,8,9-tetrahydro-5H-benzocyclohepten-5-ol (SB-612111). J Pharmacol Exp Ther 308: 454-61 [PMID:14593080]

475. Zastawny RL, George SR, Nguyen T, Cheng R, Tsatsos J, Briones-Urbina R and O'Dowd BF. (1994) Cloning, characterization, and distribution of a mu-opioid receptor in rat brain. $J$ Neurochem 62: 2099-105 [PMID:8189219]

476. Zaveri N. (2003) Peptide and nonpeptide ligands for the nociceptin/orphanin FQ receptor ORL1: research tools and potential therapeutic agents. Life Sci 73: 663-678 [PMID:12801588]

477. Zaveri NT, Journigan VB and Polgar WE. (2015) Discovery of the first small-molecule opioid pan antagonist with nanomolar affinity at mu, delta, kappa, and nociceptin opioid receptors. ACS Chem Neurosci 6: 646-57 [PMID:25635572]

478. Zhang Y, Butelman ER, Schlussman SD, Ho A and Kreek MJ. (2004) Effect of the endogenous kappa opioid agonist dynorphin A(1-17) on cocaine-evoked increases in striatal dopamine levels and cocaine-induced place preference in C57BL/6J mice. Psychopharmacology (Berl.) 172: 422-9 [PMID:14712335]

479. Zheng Y, Obeng S, Wang H, Jali AM, Peddibhotla B, Williams DA, Zou C, Stevens DL, Dewey WL and Akbarali HI et al.. (2019) Design, Synthesis, and Biological Evaluation of the Third

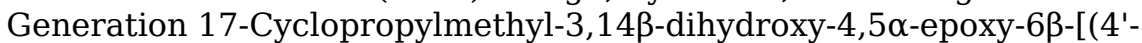
pyridyl)carboxamido]morphinan (NAP) Derivatives as $\mu / \mathrm{k}$ Opioid Receptor Dual Selective Ligands. J Med Chem 62: 561-574 [PMID:30608693]

480. Zhou L, Lovell KM, Frankowski KJ, Slauson SR, Phillips AM, Streicher JM, Stahl E, Schmid CL, Hodder P and Madoux F et al.. (2013) Development of functionally selective, small molecule agonists at kappa opioid receptors. J Biol Chem 288: 36703-16 [PMID:24187130]

481. Zhu J, Chen C, Xue JC, Kunapuli S, DeRiel JK and Liu-Chen LY. (1995) Cloning of a human kappa opioid receptor from the brain. Life Sci 56: PL201-PL207 [PMID:7869844]

482. Zhu J, Luo LY, Li JG, Chen C and Liu-Chen LY. (1997) Activation of the cloned human kappa opioid receptor by agonists enhances [35S]GTPgammaS binding to membranes: determination of potencies and efficacies of ligands. J Pharmacol Exp Ther 282: 676-84 [PMID:9262330]

483. Zhu J, Luo LY, Mao GF, Ashby B and Liu-Chen LY. (1998) Agonist-induced desensitization and down-regulation of the human kappa opioid receptor expressed in Chinese hamster ovary cells. $J$ Pharmacol Exp Ther 285: 28-36 [PMID:9535991]

484. Zhu Y, Hsu MS and Pintar JE. (1998) Developmental expression of the mu, kappa, and delta opioid receptor mRNAs in mouse. J Neurosci 18: 2538-49 [PMID:9502813]

485. Zhu Y, King MA, Schuller AG, Nitsche JF, Reidl M, Elde RP, Unterwald E, Pasternak GW and Pintar JE. (1999) Retention of supraspinal delta-like analgesia and loss of morphine tolerance in delta opioid receptor knockout mice. Neuron 24: 243-252 [PMID:10677041]

486. Zhu Y and Pintar JE. (1998) Expression of opioid receptors and ligands in pregnant mouse uterus and placenta. Biol Reprod 59: 925-32 [PMID:9746745]

487. Zimprich A, Simon T and Höllt V. (1995) Cloning and expression of an isoform of the rat mu opioid receptor (rMOR1B) which differs in agonist induced desensitization from rMOR1. FEBS Lett 359: 142-6 [PMID:7532594] 